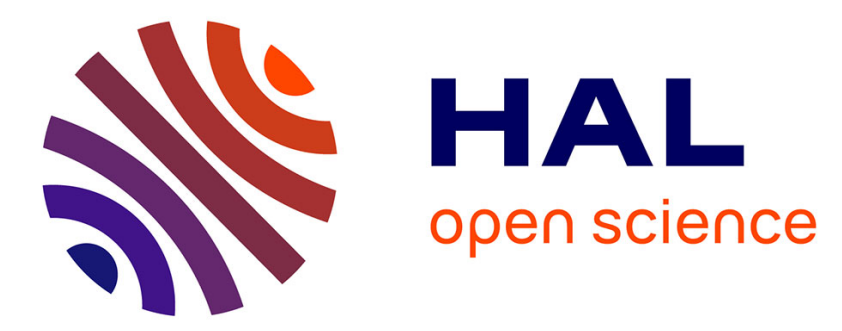

\title{
Rifted margins: Ductile deformation, boudinage, continentward-dipping normal faults and the role of the weak lower crust
}

Camille Clerc, Jean-Claude Ringenbach, Laurent Jolivet, Jean-François Ballard

\section{To cite this version:}

Camille Clerc, Jean-Claude Ringenbach, Laurent Jolivet, Jean-François Ballard. Rifted margins: Ductile deformation, boudinage, continentward-dipping normal faults and the role of the weak lower crust. Gondwana Research, 2018, 53, pp.20-40. 10.1016/j.gr.2017.04.030 . insu-01522472

\section{HAL Id: insu-01522472 \\ https://hal-insu.archives-ouvertes.fr/insu-01522472}

Submitted on 15 May 2017

HAL is a multi-disciplinary open access archive for the deposit and dissemination of scientific research documents, whether they are published or not. The documents may come from teaching and research institutions in France or abroad, or from public or private research centers.
L'archive ouverte pluridisciplinaire HAL, est destinée au dépôt et à la diffusion de documents scientifiques de niveau recherche, publiés ou non, émanant des établissements d'enseignement et de recherche français ou étrangers, des laboratoires publics ou privés.

\section{(ㅇ)(1) $\$$}

Distributed under a Creative Commons Attribution - NonCommercial - NoDerivatives| 4.0 


\section{Accepted Manuscript}

Rifted margins: Ductile deformation, boudinage, continentwarddipping normal faults and the role of the weak lower crust

Camille Clerc, Jean-Claude Ringenbach, Laurent Jolivet, JeanFrançois Ballard

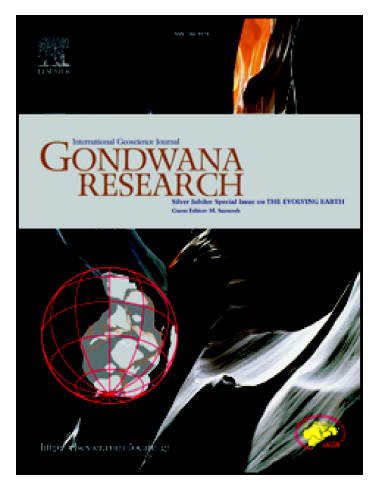

PII:

S1342-937X(17)30215-0

DOI: doi: $10.1016 /$ j.gr.2017.04.030

Reference:

GR 1802

To appear in:

Received date: $\quad 4$ July 2016

Revised date: $\quad 21$ April 2017

Accepted date: $\quad 28$ April 2017

Please cite this article as: Camille Clerc, Jean-Claude Ringenbach, Laurent Jolivet, JeanFrançois Ballard, Rifted margins: Ductile deformation, boudinage, continentward-dipping normal faults and the role of the weak lower crust, (2016), doi: 10.1016/j.gr.2017.04.030

This is a PDF file of an unedited manuscript that has been accepted for publication. As a service to our customers we are providing this early version of the manuscript. The manuscript will undergo copyediting, typesetting, and review of the resulting proof before it is published in its final form. Please note that during the production process errors may be discovered which could affect the content, and all legal disclaimers that apply to the journal pertain. 
GR Focus Review

Rifted margins: ductile deformation, boudinage, continentward-dipping normal faults and the role of the weak lower crust

Camille Clerc (1); Jean-Claude Ringenbach (2); Laurent Jolivet (3); Jean-François Ballard (2)

1: LIVE - Université de la Nouvelle Calédonie - BPR4 - 98851 Nouméa Cedex - France

2: Total SA - CSTJF - Avenue Larribau - 64000 Pau - France

3: ISTO-CNRS - Université d'Orléans - 1A rue de la Ferollerie - 45071 Orleans Cedex 2 France

Corresponding author: Camille Clerc - camille.clerc(at)univ-nc.nc 


\section{Highlights:}

- Lower crust can be weak and ductile during rifting

- Ductile crust controls boudinage and low-angle normal faults

- Continentward-Dipping Normal Faults (CDNF) control entire rifted margins 


\section{Abstract:}

The stunningly increased resolution of the deep crustal levels in recent industrial seismic profiles acquired along most of the world's rifted margins leads to the unraveling of an unexpected variety of structures. It provides unprecedented access to the processes occurring in the middle and lower continental crust. We present a series of so far unreleased profiles that allows the identification of various rift-related geological processes such as crustal boudinage, ductile shear and low-angle detachment faulting, and a rifting history that differs from the classical models of oceanward-dipping normal faults. The lower crust in rifted margins appears much more intensely deformed than usually represented. At the foot of both magma-rich and magma-poor margins, we observe clear indications of ductile deformation of the deep continental crust along large-scale shallow dipping shear zones. These shear zones generally show a top-to-the-continent sense of shear consistent with the activity of Continentward Dipping Normal Faults (CDNF) observed in the upper crust. This pattern is responsible for a migration of the deformation and associated sedimentation and/or volcanic activity toward the ocean. We discuss the origin of these CDNF and investigate their implications and the effect of sediment thermal blanketing on crustal rheology. In some cases, low-angle shear zones define an anastomosed pattern that delineates boudin-like structures. The maximum deformation is localized in the inter-boudin areas. The upper crust is intensely boudinaged and the highly deformed lower crust fills the inter-boudins underneath. The boudinage pattern controls the position and dip of upper crustal normal faults. We present some of the most striking examples from the margins of Uruguay, West Africa, South China Sea and Barents Sea, and discuss their implications for the timetemperature history of the margins.

\section{Keywords:}

Passive margin; Boudinage; Rifting; lower crust; South China Sea; Atlantic 


\section{INTRODUCTION}

Rifted margins initially form as intra-continental rifts in response to continental divergence and evolve into passive margins when a new ocean forms. Studying the margins of oceans hence provides information on the mechanisms in action during continental rifting. Rifted margins are characterized by either an absence or an abundance of magmatic material. During rifting, the nature of the continental crust, its structural inheritance and its thermal state may lead to variable modes of crustal thinning. For scientific and economic motives, most of the world's rifted margins have now been imaged by seismic reflection and improved technologies allow for everdeeper penetration and better resolution. This influx of data makes it difficult to find an example of a "classical" model of rifted margin evolution (Levell et al., 2010). Most classical models of rifting were proposed on the basis of seismic profiles that do not show the resolution and penetration of more recent acquisitions. Numerical modelling suggests that the lower crust may in specific conditions behave as a ductile medium during its exhumation (Huismans \& Beaumont, 2011; 2014) but these new images show structures in the lower crust, such as boudinage and shallow-dipping ductile shear zones that have been observed and considered in the last ten years in the Industrial World but have not been published yet. We show in this paper that the lower crust is often much weaker than classically postulated and this should lead us to reconsider rifting mechanisms in many cases.

Magma-poor rifted margins form as an answer to rifting and continental breakup without or with minimal syn-rift volcanism. Figure 1 presents some of the many models proposed for the formation of magma-poor rifted margins. Some of them imply a ductile deformation of the lower crust (Huismans and Beaumont, 2011, 2014), with fluxes toward the ocean (Fig. 1a; Driscoll and Karner, 1998; Jolivet et al., 2015) or 
toward the continent (Fig. 1b, Brun \& Beslier, 1996). Based on deep seismic data offshore United Kingdom, Reston (1988) proposes lower crust boudinage as an answer to extension (Fig. 1c). Based on their observations on the Tethyan margins preserved in the Alps and on the present-day Iberia Margin, Manatschal (2004), Péron-Pinvidic et al. (2007), Péron-Pinvidic and Manatschal (2008) and Mohn et al., (2012) proposed a model of three-layer continental crust where the brittle upper and lower crust are strongly decoupled by a ductile middle crust (Fig. 1d). The geometry of normal faults in this model, especially in the first stages, is influenced by the assumption that the lower crust is strong (intermediate or mafic) as in numerical models such as Lavier and Manatschal (2006), which leads to the formation of downward-concave normal faults for instance. Based on field observation in the pre-Pyrenean rifted margins, Clerc \& Lagabrielle (2014), propose an alternative model implying boudinage of the upper crust allowed by a high geothermal regime and blanketing effect of the decoupled thick preand syn-rift sediments (fig. Fig. 1e). Although the high temperature-low pressure metamorphism (up to $600^{\circ} \mathrm{C}$ ) recorded in these pre- and syn-rift sediment has not yet been reported from present-day passive margins this does not preclude their existence since drill holes are generally not deep enough and that such rocks are far out of target for industrial purposes.

The presence of a weak lower crust may favor an early necking and lead to an extensive spreading of the thinned continental crust (Huismans \& Beaumont, 2011; Huismans \& Beaumont, 2014). For Brune et al., (2014) spreading of the continental crust is attributed to a rift migration maintained by sequential faulting in the brittle crust and lower crustal flow. For both Huismans and Beaumont $(2011,2014)$ and Brune et al., (2014), lower crustal viscosity is a key-parameter, which strongly depends on the composition of the lower crust, its initial thermal state and the extension rate during 
rifting. By contrast, the Newfoundland/Iberia conjugate margins show a wide zone of exhumed mantle resulting from low-angle normal faults rooted in a strong lower crust and upper mantle (Péron-Pinvidic \& Manatschal, 2008).

The amount of extension measured from seismic profiles is generally insufficient to explain the amount of crustal thinning and subsidence (Ziegler, 1983; Burrus, 1984). This phenomenon, referred to as the extension discrepancy, is attributed to subseismic faulting (Marrett \& Allmendinger, 1992; Crossby et al., 2008), polyphase faulting (Reston 2005; Reston \& McDermott, 2014), sequential faulting (Ranero \& PerezGuissinyé, 2010) and/or to higher extension rates in the lower crust than in the upper crust, implying lateral flows of crustal material along shear zones (Sibuet, 1992; Davis \& Kushnir, 2004; Egan \& Meredith, 2007; Jolivet at el., 2015). Magma-rich margins are characterized by the presence of voluminous magmatic intrusion and extrusion contemporaneous with extensional tectonics (White and McKenzie, 1989; Skogseid et al., 1992). The main features of magma-rich rifted margins are: i) the presence of highvelocity seismic zones at the base of the crust: ii) a continental crust strongly intruded by sills and dikes and iii) covered with thick flood basalts and tuffs formation often imaged in seismic profiles as strongly reflective Seaward Dipping Reflectors (SDR; Barton and White, 1997; Mutter et al., 1982; White et al., 1987; White \& McKenzie, 1987).

The variety of tectonic models presented above is surpassed by the striking diversity in the geometry of the rifted margins observed worldwide. Several parameters such as the length of the margin, the thickness of the syn-rift sedimentary deposits, the behavior of the continental crust, the abundance of intrusive and extrusive magma and the vergence of normal faults differ significantly amongst margins (Fig. 2). Several Atlantic margins such as the Brazil/Angola conjugate margins present a strong necking zone followed 
seaward by a wide zone of strongly attenuated continental crust (c.a. 180km wide), underlying a thick sag basin with an apparent lack of deformation (Contrucci et al., 2004; Moulin et al., 2005; Unternehr et al., 2010; Péron-Pinvidic et al., 2015). Whereas other margins such as the Southern Angola or Aden margins appear extremely short (e.g.: Autin et al., 2010). Such large variations in the width of the deformed domain, when not resulting from oblique rifting, call for drastically different rheological behavior already suggested by numerical modeling (Huismans and Beaumont, 2011, 2014), but never identified in nature. One then expects that a weak crust will have a tendency to spread more easily and lead to a wider margin, irrespective of other parameters such as tectonic heritage, which are probably more effective during the early stages of rifting. On this basis, it seems hardly possible to use a single model to understand and predict the geometry of all the rifted margins around the world. Although we are not yet able to propose a set of kinematic models as has already been done on some highly studied margins (Boillot et al., 1987; Whitmarsh et al., 1996; Pérez-Gussinyé et al., 2003; PéronPinvidic \& Manatschal 2007; 2008), we present in this paper a selection of remarkable seismic reflection profiles that account for some geological processes rarely considered by the community of scientists working on rifted margins. We present: i) several observations in favor of a ductile behavior of the continental crust during the rifting of some rifted margins; ii) we introduce some hints in favor of tectonic boudinage at variable scales; iii) we present arguments in favor of the nucleation of rift-related lowangle normal faults; iv) we highlight the importance of the Continentward Dipping Normal Faults (CDNF) in the structuration of some rifted margins and discuss their implications. 


\section{OBSERVATIONS FROM A SELECTION OF INDUSTRIAL SEISMIC REFLECTION PROFILES}

In this section, we present a selection of high quality seismic reflection data that illustrate some peculiar tectonic processes active during the formation of rifted margins (Fig. 3). These examples come from one magma-rich rifted margin (Uruguay) and four magma-poor margins (Gabon, Southern Angola, South China Sea and Barents Sea). For each seismic profile, we highlight the first order observations and then present our interpretations.

\section{II.a. Uruguay magma-rich rifted margin}

\section{II.a.a. Observations:}

The magma-rich rifted margin of Uruguay results from the break-up of Gondwana (Rabinowitz \& Labreque, 1979; Gladczenko et al., 1997), which is pro parte contemporaneous with the emplacement of the Parana-Etendeka large igneous province (Gibson, 2006). In contrast with the magma-poor margins lying farther north, the Uruguay margin is devoid of post-rift evaporites but is characterized by thick accumulations, up to $8 \mathrm{~km}$, of Seaward Dipping Reflectors (SDR) interpreted as syn-rift volcanic formations (Stica et al., 2014; Franke et al., 2007; Clerc et al., 2015a). In the lower crust of the Urugay margin, Clerc et al, (2015a) identified two main groups of seismic reflectors (Fig. 4). A first group (A-reflectors) consists in long reflectors, continuous over tens of kilometers, especially abundant near the mantle-crust boundary. A second group consists of short reflectors (B-Reflectors) that are slightly curved and dipping toward the east and that tend to merge with the first group of reflectors. (Fig. 
4d). The concave-down geometry of the volcanics forming the SDR has sometimes been explained by subsidence models (Mutter et al., 1982; Hinz, 1981; Mutter, 1985), but alternatively, onshore and offshore investigations have pointed out that SDR are synmagmatic roll-over flexures controlled by major continentward dipping normal faults (Brooks \& Nielsen, 1982; Planke et al., 2000; Gernigon et al., 2004, 2006; Geoffroy et al., 2001, Geoffroy, 2001, 2005; Mjelde et al., 2007; Stica et al, 2014; Pindell et al., 2014). Often masked by the thick overlying SDRs, those continentward-dipping normal faults are difficult to identify in seismic reflection. Figure 5 presents an example of such a fault, clearly dipping toward the continent, and responsible for the oceanward tilt of a crustal block that supports a thick SDR wedge.

\section{II.a.b. Interpretation}

Shear patterns observed at the base of the Uruguay margin are interpreted as the testimony of a ductile behavior of the base of the continental crust. The observed ductile shear could either be related to softening of the crust favored by high heat flow above the mantle plume, possibly underlined by younger intrusions, and/or to the deformation of syn-tectonic intrusions and underplated melt (White et al., 1987; White and McKenzie, 1989; Geoffroy, 2005).

Interestingly, the reflectors observed at the base of the continental crust draw a pattern that strongly resembles the one observed in ductile shear zones of various scales (Clerc et al., 2015). The most characteristic feature calling for an analogy with ductile shear zones is the sigmoidal geometry of the small B-reflectors when approaching A-reflectors. The A-reflectors can be compared to the ductile shear planes whereas the B-reflectors are evocative of planes and objects deflected by the ductile deformation and parallelized to the shear bands. Together they draw the pattern of thick top-to-the-continent shear 
zones, consistent with the continentward dip of the normal faults that control the deposition of the SDR (Fig. 5). This observation suggests that the whole continental crust may have undergone a large-scale top-to-the-continent shearing. This further implies that, within the Ocean-Continent transition, lower crust and mantle have been exhumed by shearing during rifting, although the exact limits are difficult to position on the profiles. This behavior is similar in a first approach to the model recently proposed for the Gulf of Lion margin (Jolivet et al., 2015).

On the conjugate margins of Namibia (Fig. 1) and South Africa, several studies (Gladczenko et al., 1997; Mello et al., 2013; McDermott et al., 2015) describe comparable CDNF playing a first order role in the structuration of the margin and development of the SDR formations. The existence of SDR and of such antithetic CDNF on both sides of volcanic rifted domains (Geoffroy et al, 2015), though still debated (Becker et al., 2016), implies a symmetric disposition of structures that needs to be discussed in term of mechanical behavior (see discussion in section III.c.a)

\section{II.b. Southern Angola (Namibe) magma-poor margin}

\section{II.b.a. Observations}

Limited southward by the Walvis Ridge, the Namibe margin is located at the southern end of the post-rift evaporites that cover most of the central segment of the South Atlantic (Jackson et al., 2000; Karner and Gambôa, 2007; Heine et al., 2013). The Namibe margin is extremely narrow in comparison with its conjugate Brazilian margin (Mohriak et al., 1995; Mohriak et al., 2008; Aslanian et al., 2009; Mohriak et al., 2012; Mello et al., 2013; Moulin et al., 2013). This asymmetry has been attributed to the development of upper versus lower plate boundary (Lister et al., 1986; Péron-Pinvidic et al., 2015), with the Namibe margin being the upper plate member (Brito et al., 2004). Because it is not 
covered by thick evaporite deposits, the Namibe margin allows for a fair imaging of the rift-related structures preserved in the upper continental crust.

Profile ANG1 (courtesy of ION Geophysical), presented in figure 6, is an 87 kmlong profile that images the short Namibe margin, on the southwestern end of Angola. Numerous syn-rift basins are clearly imaged, characterized by oceanward-tilted fan reflectors.

\section{II.b.b. Interpretation}

As for volcanic rifted margins, most of the extension of the Namibe margin is accommodated by CDNF responsible for the deposition of seaward titled syn-rift deposits (Fig. 6). But, unlike volcanic rifted margins, the Namibe margin is devoid of high impedance SDR and late-rift to post-rift magmatic activity is identified only at the western tip of the margin. According to the results of Moulin et al. (2013), there is no symmetry at the scale of the rifted domain since the Namibe margin is much shorter than its conjugate Brazilian margin.

This line demonstrates that magma-poor rifted margin can also be entirely controlled by CDNF. This implies tilting of the crustal blocks toward the ocean. This has strong implications in terms of sediments trapping because i) the deepest parts of the basins are located on the offshore side of each half-graben; and ii) the tilting of the sediments adds up to the slope created by the subsidence of the margin whereas the dip of the normal faults is diminished by the subsidence of the margin (see discussion in section III.c.b).

\section{II.c. Gabon magma-poor rifted margin}

\section{II.c.a. Observations:}


The Gabon margin was formed by the rifting apart of South America and Africa during the Late Jurassic and Early Cretaceous (Rabinowitz and LaBrecque, 1979). Onshore synrift sedimentary basins on the Gabon and its conjugate Brazilian margins indicate that rifting initiated in the Neocomian (i.e. 133 Ma; Teisserenc and Villemin., 1990; Magnavita et al., 1994). In contrast with the Angola margin, the Gabon margin presents a much thicker syn-rift sedimentary cover, and a thinner sag basin (Lentini et al., 2010; Unternehr et al., 2010, Péron-Pinvidic et al., 2015). We present three profiles shot offshore the Gabonese margin. 2D Profile GA1 and 3D profile GA2 (130 km-long) are parallel and very close to each other (Fig. 7). Profile GA1 is a $245 \mathrm{~km}$-long and $24 \mathrm{~km}$ deep (courtesy of Ion Geoventure). It shows the proximal margin from nearly undeformed continental crust in the east to well-developed oceanic crust in the west. Though the crustal reflectors are partly masked and blurred by thick post-rift evaporite, one can observe that the continental crust is thinned over more than $150 \mathrm{~km}$. On top of this thinned crust, the syn-rift sediments appear tilted toward the ocean. Profile GA2, shown as a line-drawing, (Fig. 7), $130 \mathrm{~km}$-long and $16 \mathrm{~km}$-deep, shows in more details the tilt of these sediments and reveals that the sedimentary reflectors are truncated/stopped oceanward along relatively low-angle continentward dipping reflectors. In Profile GA2, the continental crust is characterized by strong sub-horizontal reflectors presenting a low amplitude / long wavelength undulation.

GA3 (Fig. 8) is a $163 \mathrm{~km}$-long 2D profile shot more than $100 \mathrm{~km}$ north of profiles GA1 and GA2, between the Koumaga and N’Komi Fracture zones (Mbina Mounguengui and Guiraud, 2009). It shares several characteristics with profiles 1 and 2: (i) two clear sets of oceanward-dipping thin sedimentary reflectors controlled by (ii) low-angle continentward-dipping normal faults that delineate (iii) an undulated top basement. A sharp bathymetric high is observed west of the shelfbreak. Although this profile is older 
and has a lower resolution close attention, It is worth noting that these features were hence already visible since the 80ies-90ies but generally ignored because unpredicted by the models in force at that time.

\section{II.c.b. Interpretation}

Similar features can be observed at different scales and resolutions on profiles 1, 2 and 3 . The syn-rift sediments are tilted toward the ocean $\left(18^{\circ}\right.$ to $\left.30^{\circ}\right)$ thanks to the activity of CDNF. Identified by Meyers et al. (1996), these reflectors were interpreted as the gradational emergence of a proto-oceanic crust. But recent data show that these reflectors are distinct from conventional magma-related Seaward Dipping Reflectors (SRDs) by their low impedance and high frequency. Furthermore, there are no gravimetric or magnetic data indicating the existence of substantial syn-rift magmatic province in the area. The bathymetric high on profile GA3 is interpreted as a magmatic structure of limited extension, similar to other extrusive magmatic bodies already identified in the area (Jackson, 2000), but volcanism is not considered as a major process for the formation of the margin (Moulin et al., 2005). We therefore question, for the Gabon margin, the existence of a thick post-tectonic sag-basin resting on top of a long and flat detachment as generally represented along West African magma-poor rifted margins (Contrucci et al., 2004; Moulin et al., 2005; Unternehr et al., 2010; PéronPinvidic et al., 2015). Instead, we observe an in-sequence migration of extensional deformation (CDNF) and associated syn-tectonic sedimentation toward the ocean. Near the most distal part of profile GA3, late syn-rift sediments are associated to an increasing proportion of magmatic rocks (purple) that announces the forthcoming initiation of break-up and crustal spreading (fig. 8). The most distal syn-rift sediments of profiles GA2 and GA3 rest on a transitional domain that may either be constituted of exhumed 
mantle or proto-oceanic crust (fig. 7 and fig. 8). The nature of that strongly reflective contact is possibly tectonic. The thick syn-tectonic sediments are in turn locally covered by small and shallow sag-basins (yellow).

Below the seaward tilted syn-rift sediments, one can observe a continental crust characterized by flat reflectors that present a low amplitude ( 3 to $5 \mathrm{~km}$ ) and long wavelength (10 to $50 \mathrm{~km}$ ) undulation. On Profiles GA1 and GA2, strong intra-crustal horizontal reflectors at $11-13 \mathrm{~km}$-depth, which is 2 to $5 \mathrm{~km}$ above the Moho, may correspond to the upper-lower crust limit visible in Martin et al. (2009) and identified by Dupré et al. (2011). These two crustal levels may be related to the two crustal levels "type I" and "type II" identified further south along the Angola Margin by Moulin et al. (2005) respectively interpreted as upper continental crust and lower (possibly intruded) continental crust. In agreement with Dupré et al., (2011), the lower crust imaged on profiles GA1, GA2 and GA3 appears irregularly shaped and presents lateral thickness variations along the direction of thinning and along the coast. We interpret these intracrustal undulations as upper crustal-scale boudins supporting oceanwardtilted syn-rift sediments above a sheared lower crust.

\section{II.d. South China Sea magma-poor margins}

\section{II.d.a. Observations}

The rifted margins of the South China Sea are devoid of salt and of SDR (Savva et al., 2014) and hence allow for a good imaging of the stretched continental crust. The triangular map-shape of the rifted domain with a SW pointing apex (Fig. 9), is indicative of a propagation opening (Courtillot, 1982; Huchon et al., 2001; Ding and Li, 2016). The "V" shape area is cored by a domain of Oligocene to Early Miocene oceanic crust. Because the South China Sea opened at the emplacement of the former long- 
lasting subduction zone of eastern Sundaland, it is characterized by a considerable amount of magmatic products uplifted and eroded since the Cretaceous (Taylor and Hayes, 1980; 1983; Schlüter et al., 1996; Pubellier et al 2003; Wang et al., 2013). Rifting could have started from the orogenic collapse of the Cretaceous Yenshanian orogen (Chen, 2010) and mainly occurred from the Early Eocene to the Oligocene (Briais et al., 1993; Barckhausen and Roeser, 2004).

To the south west of the South China Sea, at the tip of the propagator, the rifted domain presents a ribbon morphology resembling the pattern of the Basin and Range province in Western US (Fig. 9). This pattern is generally considered as an extreme, preoceanisation, crustal thinning resulting in a boudinage of the whole continental crust (Nissen et al., 1995; Franke et al., 2014; Savva et al., 2013, 2014).

In Figure 10 and Figure 11, we present line-drawings of profiles SCS1 and SCS2. These 2 profiles are parallel, distant from one another by $60 \mathrm{~km}$ and are located across the Nam Con Son and East Natuna basins, at the very tip of the oceanic propagator (Figure 9). The two profiles reveal a continental crust that is thinned and cut by normal faults over the whole length. On profile SCS1, little to undeformed $11 \mathrm{~s}$-thick (twt) continental crust is attenuated to less than $5 \mathrm{~s}$ (twt). On profile SCS2, a $9 \mathrm{~s}$-thick (twt) continental crust is thinned over more than $350 \mathrm{~km}$, and continental break-up is probably achieved between two relatively symmetric margins.

Faults dips and dip directions are highly variable across and along the margins. (i) The northwestern half of profile SCS1 is characterized by dominant shallow-dipping CDNF whereas (ii) the dip direction of normal faults on its southern half and on profile SCS2 is much more variable with normal faults dipping both toward the ocean and toward the continent. 


\section{II.d.b. Interpretation}

Both profiles reveal a widely distributed thinning of the continental crust, which is strongly thinned and spread over more than $400 \mathrm{~km}$ due to two episodes of rifting that occurred after the Yenshan orogen: the proto-South China Sea (now subducted beneath Borneo) and the South China Sea.

Profiles SCS1 and SCS2 highlight the importance of the along- and across- margin variability of the dip of normal faults. For Franke et al. (2014), this variability results from an alternating upper and lower plate configuration, but one could also invoke (i) the succession in time of several extensional events (Franke et al., 2014) or the unstable behavior of the continental crust in reason of its high thermal gradient (Cullen et al., 2010). On profile SCS2, the syn-tectonic sedimentary growth developed over the oceanward- and continentward-dipping normal faults appears diachronous. For instance, in figure $11 \mathrm{~b}$, the syn-rift sediments 1 , in red, whose deposition is compatible with the activity of detachment 1 , are overlapped by the syn-rift sediments 2 , in orange, whose pattern is consistent with the activity of detachment 2 . This change in the dip of the normal faults is responsible for the formation of crustal domes, commonly observed in the area. This example shows that most of the finite extension has been accommodated by low-angle normal faults in the upper crust and ductile thinning of the lower crust where normal faults root. The irregular topography of the Moho is a significant difference with the Basin and Range where the Moho is instead almost flat (Allmendiger et al., 1987). This difference is probably due to a larger finite extension and strain localization in a process that ultimately leads to breakup and formation of oceanic crust. Here, the upper crust is boudinaged during several episodes from Late Cretaceous to Miocene. Seismic refraction indicates that the large normal faults cutting 
through the brittle upper crust tend to flatten and root in a denser $(6.5-6.7 \mathrm{~km} / \mathrm{S})$ and smoothly-contoured material interpreted as ductile lower crust (Pichot et al., 2014).

\section{II.e. Barents sea magma-poor rift}

\section{II.e.a. Observations}

Profiles BRT1, BRT2 and BRT3 lie in the southwestern Barents Sea (Fig. 12, 13), in an aborted branch of the post-Caledonian North Atlantic rift system (Riis et al., 1986; Breivik et al., 1998). The Barents Sea opened over a part of the Caledonian orogeny, later inverted and eroded during the late Paleozoic (Gudlaugsson et al., 1998). The continental margin of the western Barents Sea developed in response to the separation of Eurasia and Greenland during the Paleogene (Talwani and Eldhom, 1977; Faleide et al., 1993). Following the orogenic collapse, the area, like the whole north Atlantic margin has undergone a long rifting history with peaks of activity during the Permian, the Jurassic, and the Early Cretaceous. Several basins, whose ages are progressively younger toward the West, are separated by basement highs (Loppa, Stappen, Veslemøy, Norsel, Senja). Gernigon et al. (2014) published a series of crustal section based on deep seismic and potential field data modeling for the western Barents Sea (Fig. 12a). In this model, the Stappen and Loppa highs (Fig. 12a, b) represent massive and rigid crustal boudins, separated by a dominantly early Cretaceous basin, developed over thinned continental crust.

BRT1 is a $190 \mathrm{~km}$-long profile across the Loppa and Veslemøy crustal high (Fig. 12c). Profiles BRT2 and BRT3, respectively 28,5 and 30,9 km-long, are from a 3D seismic block imaging the top of the Veslemøy high, down to $10 \mathrm{~km}$ depth. The area is characterized by a long low-angle reflector cutting through the sediments covering the 
top of the Veslemøy high. The deep part of the low angle reflector is not clearly visible on seismic, nor is the basement (interpretation is possible down to the top Permian only). Seismic and gravimetric modeling show that the fault cuts the whole crust down to a dome-shaped Moho level at 25km depth. Breivik et al. (2002) describe an inhomogeneous felsic to intermediate crystalline basement with seismic velocities of 6.3 $\mathrm{km} / \mathrm{s}$ at the top to $6.6 \mathrm{~km} / \mathrm{s}$ at the base. At the base of the crust, high velocities of 8.5 $\mathrm{km} / \mathrm{s}$ are attributed to either mantle or eclogites.

3D seismic provides a good to fair imaging of the hanging wall down to $10 \mathrm{~km}$, while the footwall is properly imaged down to $5-6 \mathrm{~km}$. The shallow portion of the fault is a $>1 \mathrm{~km}$ shear zone developed at the expense of the Triassic-Jurassic footwall and Cretaceous hanging wall. The hanging wall records several sets of conjugate normal faults; both antithetic and synthetic to the main shear zone, and cutting the sediments at low angle.

\section{II.e.b. Interpretations}

The necks between the crustal boudins have been characterized at low resolution in Gernigon et al. (2014). High-resolution 3D evidence the low-angle normal faults that were previously unresolved with the upper Mesozoic section. Between the Loppa and Stappen highs, large detachments appear to root in the very base of the crust and even cross through, down to the mantle, at $15 \mathrm{~km}$ to $25 \mathrm{~km}$-depth. The Veslemøy fault is very characteristic on this example; it affects the whole crust and is associated to a dome at Moho level (25km instead of $32 \mathrm{~km})$. The main activity of the fault is early Cretaceous; it has been reactivated to a lesser extent during the late Cretaceous Atlantic rifting and slightly rejuvenated after break-up. One important question is the original dip of this large-scale shear zone, was it initially steep and tilted in a later phase or was it formed with its present geometry? Thanks to 3D seismics, we were able to have a good 3D 
perception of the area and to pick and to measure the true dip of the associated minor conjugate of the normal faults. The contemporaneity of the conjugate faults is attested by their syn-sedimentary nature. We measured low dip values, ranging from $30^{\circ}$ to $60^{\circ}$ near the surface and down to ca. $14^{\circ}$ at depth (Fig. 13a). By determining the bisector of the conjugate normal faults, it is possible to estimate the orientation of the major principal stress axis $\left(\begin{array}{ll}\sigma_{1} & 1\end{array}\right)$ at the time of faulting. Because $\sigma_{1}$ is found vertical on Figure $13 \mathrm{~b}$, and in opposition with what has been observed on other low angle normal faults (Reston and McDermott, 2011), we deduce that the faults have not been tilted after their formation. Furthermore, since these faults cut through the flat and unfolded Cretaceous sediments covering the top of the Veslemøy high, we can argue that these normal faults nucleated at low angle and are most probably not resulting from the inversion of preexisting low angle thrust planes. This shows that the large-scale normal fault or extension shear zone was formed with its present low dip like other detachments around the world: in the Basin and Range (Burchfiel et al., 1987), in the Cyclades (Mehl et al., 2005; 2007; Lacombe et al., 2013) or the Norwegian Caledonides (Osmundsen and Andersen, 2001). The possibility that normal faults can nucleate and be active at lowangle is a matter of debate. For some authors, nucleation is impossible and necessarily results from the reactivation of older fault planes and/or rotation of previous higher angle normal faults (Proffett, 1977). However, mechanical activation of low-angle normal faults is theoretically possible for material presenting very low friction coefficients (phyllosilicates, clays, talc, serpentinite...) and/or high fluid pressures (Famin et al., 2004; Collettini, 2011; Lecomte et al., 2011). This may be the case for the thick and reflective shear zone observed at depth on profiles BRT2 and BRT3, though it does not explain the low-angle normal faults observed on the surface. At a larger scale, interpretation of profile BRT1 reveals that the low angle normal faults affecting the top 
of the Veslemøy high relate to the fault system delimitating the northern rim of the Veslemøy crustal boudin. This indicates that the upper crust deformation is controlled by the boudinage with low-angle normal fault nucleating in the inter-boudin. This example thus shows a large-scale boudinage of the entire crust with a shallow-dipping extensional shear zone topping the boudins.

\section{Discussion}

\section{III.a. Ductile behavior of the continental crust}

The rheology of the crust and its evolution during rifting is a matter of debate. According to numerous numerical approaches, ductile shear is suggested in the mid- to lower-crust during crustal thinning (Harry and Sawyer, 1992; Michon and Merle, 2003; Lavier and Manatschal, 2006; Van Avendonck et al., 2009; Huismans and Beaumont, 2011; 2014). However, in these models, most of the ductile deformation is localized in the middle crust whereas the lower crust is considered to be stronger and brittle (e.g. Van Avendonck et al., 2009), because resistant lower crust and upper mantle are chosen in the initial setups of these models. In contrast, other alternative quantitative models suggest a ductile behavior of the lower crust of some rifted margins following classical rheological stratification models where the lower crust is assumed to be made of intermediate to mafic material (Goetze and Evans, 1979; Le Pichon and Chamot-Rooke, 1991) or alternatively made of weaker quartz-felsic material (Hopper and Buck, 1996; Huismans and Beaumont, 2011; 2014 - Type 2; Jammes and Lavier, 2016). The examples shown in this paper suggest that for many margins the lower crust is weaker than assumed and accommodates a large part of extension by ductile shearing. Thanks to the exceptional quality of recent seismic data, Clerc et al. (2015a) identified evidences for a rift-related ductile shear at the base of the Uruguay volcanic margin (Figure 4). In 
the case of a volcanic margin such as the Uruguay one, the weakness of the crust could be related to the high heat flow related to the emerging plume and/or to the important syn-tectonic underplating and impregnation of the lower crust by magmatic melts (Franke et al., 2006; Hirsch et al., 2009). On the conjugate margin of Namibia/South Africa, high seismic velocities (up to $>7 \mathrm{~km} / \mathrm{s}$ ) also point to a gabbroic composition of the lower crust (Fromm et al., 2015).

Other evidence of ductile deformation can now be interpreted at the base of the crust along the magma-poor rifted margins of Gabon and South China Sea. Along the Gabon margin, we observe $10 \mathrm{~km}$ to $50 \mathrm{~km}$-long crustal-scale lenses that are reminiscent of boudins, so common on outcrops of ductilely deformed heterogeneous rocks. The base of the boudins, at a depth of $15 \mathrm{~km}$ to $12 \mathrm{~km}$ is separated from the Moho (17 km to 15 $\mathrm{km}$-depth) by a $3 \mathrm{~km}$ to $5 \mathrm{~km}$-thick lower crust characterized by long and sub-horizontal reflectors. This lower crustal layer is particularly evocative of a ductile behavior, especially in the inter-boudins necks where it bumps in between the stronger boudins (Figure 14a and b). The geometry of the lower crustal layer in the inter-boudin and the attitude of syn-rift sediments strongly resemble, at a different scale, the shape of the salt diapirs observed at shallow levels on the same margins as well as the sediment packages deposited during gravity gliding on the rifted margin (Figure 14c). This nearby analogy reinforces our perception that the lower part of the Gabon rifted margin behaves in a ductile way. The observed weakness of the base of the crust is possibly explained by a positive thermal anomaly during rifting suggested by Dupré et al., $(2007 ; 2011)$. The origin of this thermal anomaly is still poorly constrained, but we suggest a potential effect of the sediment thickness. Indeed, crustal boudins are covered by thick syn-rift sedimentary deposits ( 4 to $8 \mathrm{~km}$-thick) and the thick sedimentary cover is continuous, leaving no space for the heat to escape. The heating from below and insulation by 
sediment, or "blanketing effect", are regarded as major issues for the thermal history of rifted margins (Levell, 2010; Clerc et al., 2015b, 2016; Lagabrielle et al., 2016), and, as illustrated in Figure 2, it is obvious that this effect is highly variable from a margin to another, depending on the sediment thickness and nature. Numerical modeling (e.g.: Karner, 1991; Lavier and Steckler, 1997; Theissen and Rüpke, 2010) confirms the blanketing effect of the sediments and resulting weakening of the lithosphere. On the other hand, the timing of rifting and associated sedimentation is another key factor, since the rapid input of sediment also affects upper mantle thermal structure and changes the buoyancy forces in ways that enhance the localization of strain and favor an early transition to narrow-rift mode (Lizarralde et al., 2007; Bialas and Buck, 2009). It is noteworthy that a ductile flow of the lower crust associated with a crustal-scale shear affecting the entire crust can lead to lateral juxtaposition of lower and upper crust. Once brought to shallow levels or even exhumed, a ductile lower crust is expected to behave in a brittle way and thus become undistinguishable in seismic reflection from an upper crust (e.g. Jolivet et al., 2015). This aspect should be kept in mind when attempting to restore conjugate margins (cf. conservational vs. non-conservational models in Aslanian and Moulin, 2012). In the South China Sea, tectonic boudinage and ductile deformation of the continental crust have already been proposed (Savva et al., 2013) and are in agreement with previous gravity modeling (Watts and Stewart, 1998) that suggests the existence of a mechanically weak zone underlying a wide part of the margin. Here, the ductile behavior is explained by the high heat flow resulting from the rapid inversion of a former magmatic arc (Nissen et al., 1995). 


\section{III.b. Crustal boudinage}

Boudinage refers to an unstable behavior of a rheologically stratified medium subjected to extension (Goscombe and Passchier, 2004). Stronger layers are deformed by periodical localized thinning leading to sausage-shaped structures separated by necks. These structures were named boudins by analogy with some sorts of French sausage (Lohest, 1909). Depending on kinematic boundary conditions, various shapes of boudins may form, that can be either symmetrical or asymmetrical (Goscombe and Passchier, 2004). Boudins have been described on numerous outcrop scale examples but also at crustal scale (Fletcher and Hallet, 1983; Jolivet et al., 2004; Mehl et al., 2007) or even at lithospheric-scale for the Basin and Range Province (Froidevaux, 1986; Ricard and Froidevaux, 1986). The wavelength of boudinage is highly dependent upon the rheological contrast between the boudinaged layer and the matrix and also its thickness like for all periodic instabilities. In the case of the Basin and Range, crustal-scale boudins are typically 30-50 km wide and lithospheric boudins show a $200 \mathrm{~km}$ periodicity (Ricard and Froidevaux, 1986; Ricard et al., 1987). Using the word "boudins" in the case of rifting and rifted margins is thus justified.

On several of the profiles presented above, boudinage appears as a recurrent deformation process accounting for the thinning of the continental crust at variable scales. On the margin of the Barents Sea, large (several tens to hundreds km), rigid crustal blocks such as the Loppa, Stappen, or Veslemøy blocks are interpreted as thick and poorly thinned crustal boudins (Gernigon et al., 2014). These crustal blocks are separated by inter-boudins characterized by thinned and sheared crust covered by thick syn-tectonics sediments. Similar features are described by Savva et al. (2013) in the South China Sea, where thin (ca. 2 to $4 \mathrm{~s}$-TWT) and elongated (100 km to $200 \mathrm{~km}$-long) crustal boudins are separated by thick sedimentary basins floored by exhumed mantle 
peridotites. On a smaller scale, but still with comparable geometries, the distal part of the Gabon margin reveals the existence of $10 \mathrm{~km}$ to $50 \mathrm{~km}$-long boudins of upper crust (Figure 7Figure 8Figure 14). There, a network of numerous sub-horizontal reflectors in the lower crust delimitate crustal boudins, tapering at each end in an inter-boudin area controlled by low-angle $\left(10^{\circ}\right.$ to $\left.15^{\circ}\right)$ CDNF. Similar anastomosed low-angle reflectors identified in the lower crust offshore Britain were interpreted as semi-brittle shear zones (Reston, 1988).

The boudin geometry distinguishes from the classical block tilting geometry described on rifted margins by (i) the shallow dip of normal faults and (ii) the lenticular or phacoïdal geometry of the crustal blocks. Jolivet et al. (2004) and Mehl et al. (2007) highlighted the role of boudinage as an initial localizing factor by inducing the formation, near the brittle-ductile transition, of ductile shear zones at the edges of boudins. The inter-boudin necks tend to localize strain, which leads to local stress concentration and to initiation of shear zones. The shear zones are then progressively exhumed and replaced by shallow dipping cataclastic shear zones when they reach the brittle field (Jolivet et al., 2004; 2010). This process leads to a final geometry consisting in boudins of variable size, separated by low angle shear zones rooted in inter-boudin necks, as exemplified on Figure 12.

The observation of large-scale boudins in the extended crust of rifted margins calls for mechanical instabilities during rifting because of the stratification of the lithosphere, and more specifically the crust. The examples of the South China Sea or the Gabon magma-poor margins thus show a significant contrast of resistance between the upper and lower crust. The upper crust is periodically boudinaged above the weak lower crust and shallow-dipping extensional shear zones and normal faults form along the upper surface of these boudins. The exaggeration of this process leads to a 
boudinage of the whole crust (Barents Sea), possibly above a weak base of the crust or even above a hot and weak mantle.

\section{III.c. Continentward Dipping Normal Faults (CDNF)}

\section{III.c.a. Origin of the CNDF}

The dataset we selected for this study, after browsing most of the world's margins, is remarkable for the important proportion of margins controlled by CDNF, which provides us with a rather unexpected perception of the magma-poor rifted margins, traditionally represented with oceanward-dipping normal faults. The Namibe and Gabon margins are particularly striking with the whole margins being entirely controlled by CDNF. The exceptional quality of the data on profiles GA2, allows us to determine that the CDNF evolved in a sequence migrating toward the ocean, entailing with it an oceanward migration of depocenters (Fig. 7). Syntectonic sedimentation clearly results in a series of oceanward-growing and tilting sedimentary wedges, younging toward the ocean. The observation of CDNF along the Gabon margin is in accordance with previous observations (Ranero \& Pérez Gussinyé, 2010; Skogseid, 2014) and numerical models (Brune et al., 2014) but is also in relative contradiction with the description of the West African non-magmatic margins, often represented with thick and wide sag basin (Contrucci et al., 2004; Moulin et al., 2005) that is described as "subsiding vertically without differential tilting" (Aslanian et al., 2009) resting on a "highly thinned, little faulted continental crust" (Unternehr et al., 2010). For us, interpretation of profiles GA1, GA2 and GA3 indicates that most of the sedimentary basins resting on top of the highly thinned continental crust are actually syn-rift and migrate outboard until break up. This implies that improved seismic images may lead us to reconsider the existence or 
extension of some of the sag basins interpreted on the thinned crust of several rifted margins.

Equivalents of the continentward dipping normal faults of present day margins can be observed in the Jurassic distal margins exhumed in the Alps. They are the Margna fault in the Malenco area (Müntener and Hermann, 2001) and the Pogallo shear zone in the Ivrea zone (Handy and Zingg, 1991). In these localities, Mohn et al., (2012) described a necking zone characterized by an interplay of converging normal faults rooting in the ductile middle crust. These faults, dipping continentward in the lower crust (Pogallo fault) and oceanward in the upper crust (Grosina detachment), lead to the nearly complete elimination of the ductile middle crust. Once necked and sufficiently thinned, the crust becomes brittle which allows the faults to cut through, down to the mantle and exhume it at the seafloor.

These processes, very well described in the Alps, seem to apply also fairly well to the Iberian margin (Mohn et al., 2012, Manatschal, 2004, Péron-Pinvidic \& Manatschal, 2008). However, considering the important variability of the nature of the crust, the variability of its thermal state, and the diversity of extension rates, we may question the universality of this model. e.g.: Along the Cretaceous passive margins inverted in the Pyrenean range, recent work revealed the existence upper crust boudinage (Clerc and Lagabrielle, 2014; Clerc et al., 2016; Corre et al., 2016; Teixell et al., 2016) associated to strong thermal anomaly recorded in the pre-and syn-rift deposits (Clerc et al., 2015b; Lagabrielle et al., 2016). Similarly, in the South China Sea, Savva et al. (2013) described a rift related crustal deformation widely distributed over numerous lower crustal detachments indicating a rather delocalized and ductile deformation of the crust. For Savva et al. (2013), these attributes suggest that the lithosphere was possibly warmer or 
weaker during the rifting of the South China Sea. Our observations in the same regions call for a similar interpretation.

Sandbox experiments by Faugère \& Brun (1984) and Faugère (1985) revealed the relationship between the development of asymmetrical block tilting and the presence of a strong shear stress at the base of the brittle layer (Fig. 15). In these experiments, the dip direction of a normal fault is directly controlled by 2 parameters: (i) the inheritance of pre-existing tectonic discontinuities, and (ii) the sense of shear at the basal discontinuity in which the normal fault is rooted. Faugère and Brun (1984) show that the normal faults are always synthetic to the basal shear (Fig. 15). It should be noticed here that the dip of normal faults rooting within shallow-dipping extensional shear zones along the upper surface of crustal-scale boudins mentioned in the previous section fully respect these characteristics. In an application of these models to rifted margins, Brun et al. (1985) describe an interplay between two systems leading to the necking of the continental crust: (i) one corresponds to the upward migration of the Moho and affects the base of the crust with a top-to-the-continent sense of shear leading to the formation of CDNF; (ii) the other one corresponds to the subsidence of the margin, and leads to the tectonic collapse and gravity-driven décollement responsible for the formation of oceanward-dipping normal faults. By adding a layer of ductile silicone at the base of the sand layers, Vendeville et al. (1987) observed more variable dip directions of the normal fault and the formation of horst and graben which could be attributed to the decoupling effect of the ductile layer. A looser transmission of the shear stress to the base of the brittle layer would hence lead to a more random organization of the dip of normal faults. It is tempting to compare this later result to the case of the South China Sea, which is known for its hot and thus weak and ductile lithosphere and 
where we observe an important along- and across-margin variability of the dip of normal faults (Fig. 10 and Fig. 11).

Therefore, in the case of the magma-poor rifted margins of the southern Atlantic (Gabon, Southern Angola) we may envision that the continentward dip of the normal faults could be either due to a structural inheritance (Fig. 16a) or to a large-scale shear at the base of the crust due to the upward migration of the Moho during necking. In the second situation simple shear then localizes along the Moho and controls the formation of CDNF in a symmetrical fashion like in the Southern Atlantic (Uruguay and Namibia conjugate margins; Fig. 2 ; Fig. 16 b and c). Along the volcanic margin of Uruguay, this second hypothesis of a crustal shear at the origin of the formation of CDNF is indeed attested by the top-to-the-continent ductile fabric observed in the middle and lower crust (Clerc et al., 2015a). The shear pattern in the lower crust and the normal faults in the upper crust of the Uruguay margin show a component of simple shear distributed across the entire continental crust, thus suggesting a relative motion of the mantle with respect to the continental crust. When considering the conjugate southern Namibian and South African margins (Gladczenko et al., 1997; Blaich et al., 2013; Mello et al., 2013) we note a relative symmetry of the rift system since CDNF control the formation of SDR on both sides of the conjugate volcanic margins (Fig. 2).

A model supporting both (i) the top-to-the-continent basal shear and (ii) the existence of CDNF on each side of the rifted domain is also compatible with a gravitational collapse of a plume head-related topographic bulge for the volcanic margins (Fig. 16c). For instance, Griffiths and Campbell (1991) predict that the rise of a surface uplift around $400 \mathrm{~km}$ to $600 \mathrm{~km}$ wide can be expected above a $500 \mathrm{~km}$ radius plume head. We suggest that such a topography, in conjunction with the extension responsible for the opening of the Atlantic rift system could lead to a gravity collapse of the bulge resulting in a top-to- 
the-continent shear sense on each side of the rift. Lubrication of the base of the crust by intrusive and underplated magmas could weaken the crust and favor its collapse.

Because of the development of CDNF the crustal blocks are tilted towards the ocean. Later the rifted margin subsidence increases the dip. The resulting dip of the pre- and syn-rift sediments deposited on margins controlled by CDNF hence presents higher absolute tilt values than those deposited on margins controlled by oceanward-dipping normal faults (Fig. 17). For the same reasons, the fault angle is lower on CDNF margins than on oceanward-dipping normal faults margins. For instance, on the CDNF-controlled margins of Southern Angola and Gabon, we observe that the syn-rift sediments are tilted oceanward by respectively $20^{\circ}$ to $35^{\circ}$ (Profile ANG1) and $18^{\circ}$ to $30^{\circ}$ (profile GA2). In contrast, the syn-rift sediments of the Iberian margin, present lower tilt values, circa $5^{\circ}$ to $25^{\circ}$ (determined after Manatschal, 2004).

\section{Conclusion:}

As a first order key-point we put forward the important variability in the geometry of the present-day rifted margins. Numerous structural parameters such as the length of the margin, the sediment thickness, the dip direction of the normal faults, the abundance of syn-rift material, the inherited thermal state of the lithosphere, and the extension rate during rifting are extremely variable from a margin to another (Fig. 1). To support this assertion and to investigate further the possible mechanisms responsible for that variability, we have presented a new set of high-resolution seismic reflection profiles from rifted margins of Uruguay, Southern Namibia, Gabon, South China Sea and Barents

Sea. This dataset allows us to highlight several tectonic features along these margins:

- Ductile deformation at the base of the crust is imaged on the margins of Uruguay, Gabon and South China Sea. This ductile behavior of a weak lower crust is 
attributed to an elevated thermal gradient possibly related to (i) a blanketing effect of the syn-rift sediments (Gabon); (ii) to an inherited high thermal gradient (collapsing arc, South China Sea); or (iii) to a plume related thermal anomaly (Uruguay). The frequent weakness of the lower crust, already suggested by earlier numerical models, is now confirmed and clearly imaged by seismic reflection, which should lead to reconsidering models of continental rifting.

- Tectonic boudinage of the continental crust plays an important role during the structuration of the Gabon, Barents, and South China Sea margins. This boudinage is another indication of the weakness of the lower crust. It explains the periodicity of normal faults and the focusing of deformation in the interboudin necks. It favors the development of shallow-dipping crustal-scale shear zones and allow for the nucleation of low-angle normal faults. Boudinage and low-angle-normal faults are thus direct consequences of the rheological heterogeneity of the crust and the weakness of the lower crust similar to examples of post-orogenic extension such as the Basin and Range or the Aegean.

- Continentward Dipping Normal Faults (CDNF), probably underestimated until now, are frequent and can control the formation of an entire rifted margin (e.g., Southern Angola, Uruguay...). At the scale of the entire rift (conjugate margins) the fault pattern can be symmetrical, especially in the case of volcanic rifted margins (Fig. 18a). In this case, CDNF are observed on either side, dipping away from the rift centre. Depending on the case, we propose three mechanisms for their formation: i) inversion of inherited faults, that leads to asymmetric conjugate margins; ii) formation above a basal shear possibly related to lithosphere-asthenosphere relative motion, also leading to asymmetric conjugate margins (Fig. 18b); iii) Syn-magmatic gravity collapse above a rising plume head 
which, in this case, leads to symmetric conjugate volcanic margins (eg. UruguayNamibia margins, Fig. 2 and Fig. 18a).

The observation and interpretation of high-quality and deep penetration seismic profiles in several locations leads to an unorthodox vision of rifted margins where the lower crust is weak. Boudinage controls a large part of the deformation and localization of low-angle normal faults, and these normal faults often dip toward the continent (Fig. 18b). Whether these margins are representative of a significant part of rifted margins around the oceans is difficult to assess given the relatively small number of analyzed profiles, but these profiles sample depths that have seldom been imaged before with such details and thus they are the only window we have so far on the behavior of the lower crust in extensional contexts. At the very least, they show that the more classical upper/lower plate asymmetrical models with normal faults dipping toward the ocean, and which involve more resistant rheologies for the lower crust represent merely one category of rifted margins, probably the "cold" ones. "Hot" and hence ductile margins, whether volcanic or not, present a wider distribution of deformation, a lower taper angle, and the characteristics related to a weak lower crust mentioned above (Fig. 18b), while "cold" margins would show a more localized deformation, and a higher taper angle. 


\section{Acknowledgements:}

We are grateful to Total SA for funding and offering access to the seismics. We thank Schlumberger Multiclient, Petrolin, TGS, Marathon, Cobalt and Ion Geophysical for providing outstanding seismic profiles and allowing us to publish them. The Gabonese DGH is thanked for the access to the Gabonese profiles. Emily Clerc greatly helped to improve the English. This work was funded by Total through a postdoc grant to C. Clerc. This paper is a contribution of the ERC Advanced Research Grant RHEOLITH (grant agreement No.290864), of Institut Universitaire de France and Labex VOLTAIRE. 


\section{Figure Caption}

Figure 1: Some of the many models proposed for the behavior of the continental crust during the formation of rifted margins (modified after Reston, 2007).

Figure 2: Variability in length of the margin, abundance of syn-rift deposits (sediments and/or volcanics), dip direction of the normal faults and general crustal behavior of the continental crust at rifted margins. Compilation from 15 rifted margins from this study and reproduced from Péron-Pinvidic and Manatschal, (2008); Autin et al., (2010); Jolivet et al., (2015); Gernigon et al., 2014; Tsikalas et al., (2008); Unternehr et al., (2010); Osmundsen and Ebbing, (2008); Clerc et al., (2015a); Mc Dermott et al., (2015); Geoffroy et al., (2015); Gladczenko et al, (1998).

Figure 3: Location map for the 6 study areas. Basemap from http://www.geomapapp.org and Ryan et al. (2009), Repartition of the types of margins modified after Haupert et al. (2016). NAVP: North Atlantic Volcanic Province.

Figure 4: a) Regional map of the southern Atlantic Ocean after Gladczenko et al., (1997), Stica et al., (2014) and Soto et al. (2011), basemap from http://www.geomapapp.org and Ryan et al. (2009). b) Magnetic anomaly map of the Uruguayan rifted margin after Maus et al., (2009). c) Interpretation of profile UR1 and d) close-up on the shear patterns at the base of the lower crust (Clerc et al., 2015a). Data courtesy of ION Geophysical.

Figure 5: Profile UR2 and close-up on a SDR wedge and associated continentward dipping normal fault. Data courtesy of ION Geophysical 
Figure 6: Map of West Africa showing the localisation of profiles GA1, GA2, GA3 and ANG1. Basemap from http://www.geomapapp.org and Ryan et al. (2009). Profile ANG1 and interpretation.

Figure 7: Profiles 1 and 2 from the Gabon rifted margin. Both profiles are parallel and roughly superposed. Approximate projection of profile GA2 on profile GA1 in indicated by the red box. See map on Figure 6 for location. Data courtesy of ION Geophysical (profile GA1), Total, Marathon and Cobalt (profile GA2).

Figure 8: Seismic reflection profile GA3, line-drawing and interpretation across the Gabon margin, More than 100km north of profiles GA1 \& GA2. See map on figure 6 for location. Data courtesy of Schlumberger Multiclient and Petrolin.

Figure 9: Map of the South China Sea showing the main structural features, after Savva et al., 2013, 2014; Franke et al., 2014. Profiles SCS1 and SCS2 are located at the southwestern tip of the South China Sea propagator.

Figure 10: Profile SCS1, across the Nam Con Son basin, located ahead the propagator of the South China Sea. Data courtesy of TGS.

Figure 11: A: Profile SCS2 across the Nam Con Son Basin, located $60 \mathrm{~km}$ northeast of profile SCS1. The seismic profile is available from fig. 5A of Franke et al., 2014. B. Zoom on a crustal Dome at the intersection of two antithetic detachements. Data courtesy of TGS.

Figure 12: a) Interpretation of the Barents margin redrawn after Gernigon et al. (2014). b) Localization map for profiles G, H, BRT1, BRT2 and BRT3, redrawn after Faleide et al. (1984) and Gernigon et al. (2014). c) Profile BRT1 across the Loppa and Veslemøy highs. 
Figure 13: Profiles BRT2 (a) and BRT3 (b) across the Veslemøy crustal high (data courtesy of Schlumberger). Nucleation of low angle normal faults is attested from profile BRT2 (a), which is orthogonal to the faults strike (determined from 3D seismic block). b) The major principal stress $\sigma 1$ is found vertical on BRT3 by determining the bisector of the conjugate antithetic normal faults, which attests for the absence of post-fault tilting. The low angle between the faults and the sedimentary bedding, and the tiny rotation of these series also confirms that the faults nucleate at low angle

Figure 14: a) interpretations of seismic profiles across the magma-poor margin of Gabon, a few tens of kilometers south of profile GA2. Courtesy of Total, Marathon and Cobalt. b) Comparison with similar structures observed at a completely different scale, in the rafted post-salt sediments. Localisation in (a). c) Comparison with a model of crustal boudinage, redrawn after Gartrell (1997)

Figure 15: a) Sand model uniformly stretched by downslope planar normal faults, redrawn after Vendeville et al., 1987. b) Sandbox experiment showing the progression of deformation sequence trough an extensional wedge, photograph and redrawn from Xiao et al., 1991 and Yin, 1994. The locus of active synthetic normal faulting moves from the back to the front of the wedge (from right to left on the photograph). Comparison with profile profile ANG1 (c) suggests the existence a major shear at the base of the continental crust.

Figure 16: Possible scenario for the formation of Continentward Dipping Normal Faults (CDNF). a) formation of CDNF by inversion of inherited structures (former thrusts); The formation of CDNF can also be controlled by the existence of top-to-the-continent shear at the base of the crust. This shear could results either from (b) a basal drag of the 
mantle due to mantle drift; or (c) in the case of volcanic rifted margins to the collapse of a topographic anomaly above an emerging plume.

Figure 17: Implication of fault dip on the tilt of the crustal blocks. On CDNF-controlled margins, bloc-related tilting adds up to the subsidence-related tilting. Whereas on margins controlled by oceanward-dipping normal faults, block tilting (toward the continent) is opposed to subsidence-related tilting (toward the ocean).

Figure 18: Schematic representation of the volcanic rifted margins and ductile-type magma-poor rifted margin. 


\section{References:}

Allmendiger, R.W., Hauge, T.A., Hauser, C.J., Potter, S.L., Klemperer, K.D., Nelson, P., Knuepfer, P., Oliver, J., 1987. Overview of the COCORP $40^{\circ} \mathrm{N}$ Transect, western United States: the fabric of an orogenic belt. Geol. Soc. Am. Bull. 98, 308-319.

Aslanian, D., Moulin, M., Olivet, J.-L., Unternehr, P., Matias, L., Bache, F., Rabineau, M., Nouzé, H., Klingelheofer, F., Contrucci, I., Labails, C., 2009. Brazilian and African passive margins of the Central Segment of the South Atlantic Ocean: Kinematic constraints. Tectonophysics, Role of magmatism in continental lithosphere extension continental lithosphere extension 468, 98-112. doi:10.1016/j.tecto.2008.12.016

Autin, J., Leroy, S., Beslier, M.-O., D’Acremont, E., Razin, P., Ribodetti, A., Bellahsen, N., Robin, C., Al Toubi, K., 2010. Continental break-up history of a deep magma-poor margin based on seismic reflection data (northeastern Gulf of Aden margin, offshore Oman). Geophys. J. Int. 180, 501-519. doi:10.1111/j.1365246X.2009.04424.x

Barckhausen, U., Roeser, H.A., 2004. Seafloor Spreading Anomalies in the South China Sea Revisited, in: Clift, P., Kuhnt, W., Wang, P., Hayes, D. (Eds.), Continent-Ocean Interactions Within East Asian Marginal Seas. American Geophysical Union, pp. $121-125$.

Barton, A.J., White, R.S., 1997. Volcanism on the Rockall continental margin. J. Geol. Soc. 154, 531-536. doi:10.1144/gsjgs.154.3.0531

Becker, K., Tanner, D.C., Franke, D., Krawczyk, C.M., 2016. Fault-controlled lithospheric detachment of the volcanic southern South Atlantic rift. Geochem. Geophys. Geosystems n/a-n/a. doi:10.1002/2015GC006081 
Bialas, R.W., Buck, W.R., 2009. How sediment promotes narrow rifting: Application to the Gulf of California. Tectonics 28, TC4014. doi:10.1029/2008TC002394

Blaich, O.A., Faleide, J.I., Tsikalas, F., Gordon, A.C., Mohriak, W., 2013. Crustal-scale architecture and segmentation of the South Atlantic volcanic margin. Geol. Soc. Lond. Spec. Publ. 369, 167-183. doi:10.1144/SP369.22

Boillot, G., Winterer, E.L., Meyer, A.W., et al. (Eds.), 1987. Proceedings of the Ocean Drilling Program, 103 Initial Reports. Ocean Drilling Program.

Breivik, A.J., Faleide, J.I., Gudlaugsson, S.T., 1998. Southwestern Barents Sea margin: late Mesozoic sedimentary basins and crustal extension. Tectonophysics 293, 21-44. doi:10.1016/S0040-1951(98)00073-0

Briais, A., Patriat, P., Tapponnier, P., 1993. Updated interpretation of magnetic anomalies and seafloor spreading stages in the south China Sea: Implications for the Tertiary tectonics of Southeast Asia. J. Geophys. Res. Solid Earth 98, 6299-6328. doi:10.1029/92JB02280

Brito, M., Figueiredo, C., Inkollu, M., 2004. Namibe Basin: Deepwater Exploration Potential. AAPG Int. Conf. Exhib. 14-18 Novemb. 2004 Abuja Niger.

Brooks, C.K., Nielsen, T.F.D., 1982. The E Greenland continental margin: a transition between oceanic and continental magmatism. J. Geol. Soc. 139, 265-275. doi:10.1144/gsjgs.139.3.0265

Brun, J.P., Beslier, M.O., 1996. Mantle exhumation at passive margins. Earth Planet. Sci. Lett. 142, 161-173. doi:10.1016/0012-821X(96)00080-5

Brun, J.-P., Choukroune, P., Faugeres, E., 1985. Les discontinuites significatives de l'amincissement crustal; application aux marges passives. Bull. Soc. Geol. Fr. I, 139144. doi:10.2113/gssgfbull.I.1.139 
Brune, S., Heine, C., Pérez-Gussinyé, M., Sobolev, S.V., 2014. Rift migration explains continental margin asymmetry and crustal hyper-extension. Nat. Commun. 5. doi:10.1038/ncomms5014

Burchfiel, B.C., Hodges, K.V., Royden, L.H., 1987. Geology of Panamint Valley-Saline Valley pull-apart system, California; palinspastic evidence for low-angle geometry of a Neogene range-bounding fault. J. Geophys. Res. 92, 10422-10426.

Burrus, J., 1984. Contribution to a geodynamic synthesis of the Provençal Basin (NorthWestern Mediterranean). Mar. Geol. 55, 247-269. doi:10.1016/0025$3227(84) 90071-9$

Chen, Y., Niu, F., Liu, R., Huang, Z., Tkalčić, H., Sun, L., Chan, W., 2010. Crustal structure beneath China from receiver function analysis. J. Geophys. Res. Solid Earth 115, B03307. doi:10.1029/2009JB006386

Clerc, C., Lagabrielle, Y., 2014. Thermal control on the modes of crustal thinning leading to mantle exhumation. Insights from the Cretaceous Pyrenean hot paleomargins. Tectonics 2013TC003471. doi:10.1002/2013TC003471

Clerc, C., Jolivet, L., Ringenbach, J.-C., 2015a. Ductile extensional shear zones in the lower crust of a passive margin. Earth Planet. Sci. Lett. 431, 1-7.

doi:10.1016/j.epsl.2015.08.038

Clerc, C., Lahfid, A., Monié, P., Lagabrielle, Y., Chopin, C., Poujol, M., Boulvais, P., Ringenbach, J.-C., Masini, E., de St Blanquat, M., 2015b. High-temperature metamorphism during extreme thinning of the continental crust: a reappraisal of the North Pyrenean passive paleomargin. Solid Earth 6, 643-668. doi:10.5194/se6-643-2015

Clerc, C., Lagabrielle, Y., Labaume, P., Ringenbach, J.-C., Vauchez, A., Nalpas, T., Bousquet, R., Ballard, J.-F., Lahfid, A., Fourcade, S., 2016. Basement - Cover decoupling and 
progressive exhumation of metamorphic sediments at hot rifted margin. Insights from the Northeastern Pyrenean analog. Tectonophysics.

doi:10.1016/j.tecto.2016.07.022

Collettini, C., 2011. The mechanical paradox of low-angle normal faults: Current understanding and open questions. Tectonophysics 510, 253-268. doi:10.1016/j.tecto.2011.07.015

Coffin, M.F., Eldholm, O., 1994. Large igneous provinces: Crustal structure, dimensions, and external consequences. Rev. Geophys. 32, 1-36. doi:10.1029/93RG02508

Corre, B., Lagabrielle, Y., Labaume, P., Fourcade, S., Clerc, C., Ballèvre, M., 2016. Deformation associated with mantle exhumation in a distal, hot passive margin environment: New constraints from the Saraillé Massif (Chaînons Béarnais, NorthPyrenean Zone). Comptes Rendus Geosci. 348, 279-289. doi:10.1016/j.crte.2015.11.007

Contrucci, I., Matias, L., Moulin, M., Géli, L., Klingelhofer, F., Nouzé, H., Aslanian, D., Olivet, J.L., Réhault, J.-P., Sibuet, J.-C., 2004. Deep structure of the West African continental margin (Congo, Zaïre, Angola), between $5^{\circ} \mathrm{S}$ and $8^{\circ} \mathrm{S}$, from reflection/refraction seismics and gravity data. Geophys. J. Int. 158, 529-553. doi:10.1111/j.1365246X.2004.02303.X

Courtillot, V., 1982. Propagating rifts and continental breakup. Tectonics 1, 239-250. doi:10.1029/TC001i003p00239

Crosby, A., White, N., Edwards, G., Shillington, D.J., 2008. Evolution of the NewfoundlandIberia conjugate rifted margins. Earth Planet. Sci. Lett. 273, 214-226. doi:10.1016/j.epsl.2008.06.039 
Cullen, A., Reemst, P., Henstra, G., Gozzard, S., Ray, A., 2010. Rifting of the South China Sea: new perspectives. Pet. Geosci. 16, 273-282. doi:10.1144/1354-079309-908

Davis, M., Kusznir, N., 2004. Depth-dependent lithospheric stretching at rifted continental margins, in: Proceedings of NSF Rifted Margins Theoretical Institute. G.D. Karner, United States, pp. 92-137.

Ding, W., Li, J., 2016. Propagated rifting in the Southwest Sub-basin, South China Sea: Insights from analogue modelling. J. Geodyn. doi:10.1016/j.jog.2016.02.004

Driscoll, N.W., Karner, G.D., 1998. Lower crustal extension across the Northern Carnarvon basin, Australia: Evidence for an eastward dipping detachment. J. Geophys. Res. Solid Earth 103, 4975-4991. doi:10.1029/97JB03295

Dupré, S., Bertotti, G., Cloetingh, S., 2007. Tectonic history along the South Gabon Basin: Anomalous early post-rift subsidence. Mar. Pet. Geol. 24, 151-172. doi:10.1016/j.marpetgeo.2006.11.003

Dupré, S., Cloetingh, S., Bertotti, G., 2011. Structure of the Gabon Margin from integrated seismic reflection and gravity data. Tectonophysics 506, 31-45. doi:10.1016/j.tecto.2011.04.009

Egan, S.S., Meredith, D.J., 2007. A kinematic modelling approach to lithosphere deformation and basin formation: application to the Black Sea. Geol. Soc. Lond. Spec. Publ. 282,173-198. doi:10.1144/SP282.9

Faleide, J.I., Gudlaugsson, S.T., Jacquart, G., 1984. Evolution of the western Barents Sea. Mar. Pet. Geol. 1, 123-150. doi:10.1016/0264-8172(84)90082-5

Faleide, J.I., Vågnes, E., Gudlaugsson, S.T., 1993. Late Mesozoic-Cenozoic evolution of the south-western Barents Sea in a regional rift-shear tectonic setting. Mar. Pet. Geol. 10, 186-214. doi:10.1016/0264-8172(93)90104-Z 
Famin, V., P. Philippot, L. Jolivet, and P. Agard (2004), Evolution of hydrothermal regime along a crustal shear zone, Tinos island, Greece, Tectonics, 23, doi:10.1029/2003TC001509.

Faugeres, E., 1985. La Tectonique en extension intracontinentale : étude de terrain, le Sud du Nevada, U.S.A., et modélisation analogique.

Faugeres, E., Brun, J.-P., 1984. Modelisation expérimentale de la distension continentale. C R Acad Sci Paris 299, 365.

Fletcher, R.C., Hallet, B., 1983. Unstable extension of the lithosphere: a mechanical model for Basin-and-Range structure. J. Geophys. Res 88, 7457-7466.

Franke, D., Neben, S., Ladage, S., Schreckenberger, B., Hinz, K., 2007. Margin segmentation and volcano-tectonic architecture along the volcanic margin off Argentina/Uruguay, South Atlantic. Mar. Geol. 244, 46-67. doi:10.1016/j.margeo.2007.06.009

Franke, D., Neben, S., Schreckenberger, B., Schulze, A., Stiller, M., Krawczyk, C.M., 2006. Crustal structure across the Colorado Basin, offshore Argentina. Geophys. J. Int. 165, 850-864. doi:10.1111/j.1365-246X.2006.02907.x

Franke, D., Savva, D., Pubellier, M., Steuer, S., Mouly, B., Auxietre, J.-L., Meresse, F., Chamot-Rooke, N., 2014. The final rifting evolution in the South China Sea. Mar. Pet. Geol., Evolution, Structure, and Sedimentary Record of the South China Sea and Adjacent Basins 58, Part B, 704-720. doi:10.1016/j.marpetgeo.2013.11.020

Froidevaux, C., 1986. Basin and Range large-scale tectonics: constraints from gravity and reflection seismology. J. Geophys. Res. 91, 3625-3632.

Fromm, T., Planert, L., Jokat, W., Ryberg, T., Behrmann, J.H., Weber, M.H., Haberland, C., 2015. South Atlantic opening: A plume-induced breakup? Geology 43, 931-934. doi:10.1130/G36936.1 
Gartrell, A.P., 1997. Evolution of rift basins and low-angle detachments in multilayer analog models. Geology 25, 615-618. doi:10.1130/00917613(1997)025<0615:EORBAL>2.3.CO;2

Geoffroy, L., 2001. The structure of volcanic margins: some problematics from the North-Atlantic/ Labrador-Baffin system. Mar. Pet. Geol. 18, 463-469. doi:10.1016/S0264-8172(00)00073-8

Geoffroy, L., Callot, J.-P., Scaillet, S., Skuce, A., Gélard, J.P., Ravilly, M., Angelier, J., Bonin, B., Cayet, C., Perrot, K., Lepvrier, C., 2001. Southeast Baffin volcanic margin and the North American-Greenland plate separation. Tectonics 20, 566-584. doi:10.1029/2001TC900003

Geoffroy, L., 2005. Volcanic passive margins. Comptes Rendus Geosci. 337, 1395-1408. doi:10.1016/j.crte.2005.10.006

Geoffroy, L., Burov, E.B., Werner, P., 2015. Volcanic passive margins: another way to break up continents. Sci. Rep. 5. doi:10.1038/srep14828

Gernigon, L., Lucazeau, F., Brigaud, F., Ringenbach, J.-C., Planke, S., Le Gall, B., 2006. A moderate melting model for the Vøring margin (Norway) based on structural observations and a thermo-kinematical modelling: Implication for the meaning of the lower crustal bodies. Tectonophysics 412, 255-278. doi:10.1016/j.tecto.2005.10.038

Gernigon, L., Ringenbach, J.-C., Planke, S., Le Gall, B., 2004. Deep structures and breakup along volcanic rifted margins: insights from integrated studies along the outer Vøring Basin (Norway). Mar. Pet. Geol. 21, 363-372. doi:10.1016/j.marpetgeo.2004.01.005 
Gernigon, L., Brönner, M., Roberts, D., Olesen, O., Nasuti, A., Yamasaki, T., 2014. Crustal and basin evolution of the southwestern Barents Sea: From Caledonian orogeny to continental breakup. Tectonics 33, 2013TC003439. doi:10.1002/2013TC003439

Gibson, S.A., Thompson, R.N., Day, J.A., 2006. Timescales and mechanisms of plumelithosphere interactions: 40Ar/39Ar geochronology and geochemistry of alkaline igneous rocks from the Paraná-Etendeka large igneous province. Earth Planet. Sci. Lett. 251, 1-17. doi:10.1016/j.epsl.2006.08.004

Gladczenko, T.P., Hinz, K., Eldholm, O., Meyer, H., Neben, S., Skogseid, J., 1997. South Atlantic volcanic margins. J. Geol. Soc. 154, 465-470. doi:10.1144/gsjgs.154.3.0465 Gladczenko, T.P., Skogseid, J., Eldhom, O., 1998. Namibia volcanic margin. Mar. Geophys. Res. 20, 313-341. doi:10.1023/A:1004746101320

Goetze, C., Evans, B., 1979. Stress and temperature in the bending lithosphere as constrained by experimental rock mechanics. Geophys. J. R. Astron. Soc. 59, 463478.

Goscombe, B.D., Passchier, C.W., Hand, M., 2004. Boudinage classification: end-member boudin types and modified boudin structures. Journal of Structural Geology 26, 739-763.

Griffiths, R.W., Campbell, I.H., 1991. Interaction of mantle plume heads with the Earth's surface and onset of small-scale convection. J. Geophys. Res. Solid Earth 96, 1829518310. doi:10.1029/91JB01897

Gudlaugsson, S.T., Faleide, J.I., Johansen, S.E., Breivik, A.J., 1998. Late Palaeozoic structural development of the South-western Barents Sea. Mar. Pet. Geol. 15, 73102. doi:10.1016/S0264-8172(97)00048-2

Handy, M.R., Zingg, A., 1991. The tectonic and rheological evolution of an attenuated cross section of the continental crust: Ivrea crustal section, southern Alps, 
northwestern Italy and southern Switzerland. Geol. Soc. Am. Bull. 103, 236-253. doi:10.1130/0016-7606(1991)103<0236:TTAREO>2.3.CO;2

Harry, D.L., Sawyer, D.S., 1992. A dynamic model of extension in the Baltimore Canyon Trough Region. Tectonics 11, 420-436. doi:10.1029/91TC03012

Haupert, I., Manatschal, G., Decarlis, A., Unternehr, P., 2016. Upper-plate magma-poor rifted margins: Stratigraphic architecture and structural evolution. Mar. Pet. Geol. 69, 241-261. doi:10.1016/j.marpetgeo.2015.10.020

Heine, C., Zoethout, J., Müller, R.D., 2013. Kinematic of the South Atlantic rift. Solid Earth 4, 215-253. doi:doi:10.5194/se-4-215-2013

Hinz, K., 1981. A hypothesis on terrestrial catastrophes: wedges of very thick oceanward dipping layers beneath passive continental margins ; their origin and paleoenvironmental significance. Schweizerbart.

Hirsch, K.K., Bauer, K., Scheck-Wenderoth, M., 2009. Deep structure of the western South African passive margin - Results of a combined approach of seismic, gravity and isostatic investigations. Tectonophysics, Progress in understanding sedimentary basins 470, 57-70. doi:10.1016/j.tecto.2008.04.028

Hopper, J.R., Buck, W.R., 1996. The effect of lower crustal flow on continental extension and passive margin formation. J. Geophys. Res. Solid Earth 101, 20175-20194. doi:10.1029/96JB01644

Huchon, P., Nguyen, T.N.H., Chamot-Rooke, N., 2001. Propagation of continental breakup in the southwestern South China Sea. Geol. Soc. Lond. Spec. Publ. 187, 31-50. doi:10.1144/GSL.SP.2001.187.01.03

Huismans, R., Beaumont, C., 2011. Depth-dependent extension, two-stage breakup and cratonic underplating at rifted margins. Nature 473, 74-78. doi:10.1038/nature09988 
Huismans, R.S., Beaumont, C., 2014. Rifted continental margins: The case for depthdependent extension. Earth Planet. Sci. Lett. 407, 148-162. doi:10.1016/j.epsl.2014.09.032

Jackson, M.P.A., Cramez, C., Fonck, J.-M., 2000. Role of subaerial volcanic rocks and mantle plumes in creation of South Atlantic margins: implications for salt tectonics and source rocks. Mar. Pet. Geol. 17, 477-498. doi:10.1016/S02648172(00)00006-4

Jammes, S., Lavier, L.L., 2016. The effect of bimineralic composition on extensional processes at lithospheric scale. Geochem. Geophys. Geosystems 17, 3375-3392. doi:10.1002/2016GC006399

Jolivet, L., Famin, V., Mehl, C., Parra, T., Aubourg, C., Hébert, R., Philippot, P., 2004. Strain localization during crustal-scale boudinage to form extensional metamorphic domes in the Aegean Sea. Geol. Soc. Am. Spec. Pap. 380, 185-210. doi:10.1130/08137-2380-9.185

Jolivet, L., Gorini, C., Smit, J., Leroy, S., 2015. Continental breakup and the dynamics of rifting in back-arc basins: The Gulf of Lion margin. Tectonics 34, 2014TC003570. doi:10.1002/2014TC003570

Jolivet, L., Labrousse, L., Agard, P., Lacombe, O., Bailly, V., Lecomte, E., Mouthereau, F., Mehl, C., 2010. Rifting and shallow-dipping detachments, clues from the Corinth Rift and the Aegean. Tectonophysics 483, 287-304. doi:10.1016/j.tecto.2009.11.001

Karner, G.D., 1991. Sediment blanketing and the flexural strength of extended continental lithosphere. Basin Res. 3, 177-185. doi:10.1111/j.13652117.1991.tb00127.x 
Lavier, L.L., Steckler, M.S., 1997. The effect of sedimentary cover on the flexural strength of continental lithosphere. Nature 389, 476-479. doi:10.1038/39004

Karner, G.D., Gambôa, L. a. P., 2007. Timing and Origin of the South Atlantic Pre-Salt Sag Basins and Their Capping Evaporites. Geol. Soc. Lond. Spec. Publ. 285, 15-35. doi:10.1144/SP285.2

Lacombe, O., Jolivet, L., Le Pourhiet, L., Lecomte, E., Mehl, C., 2013. Initiation, geometry and mechanics of brittle faulting in exhuming metamorphic rocks: insights from the northern Cycladic islands (Aegean, Greece). Bull Soc géol France 184, 383-403. Lagabrielle, Y., Clerc, C., Vauchez, A., Lahfid, A., Labaume, P., Azambre, B., Fourcade, S., Dautria, J.-M., 2016. Very high geothermal gradient during mantle exhumation recorded in mylonitic marbles and carbonate breccias from a Mesozoic Pyrenean palaeomargin (Lherz area, North Pyrenean Zone, France). Comptes Rendus Geosci. 348, 290-300. doi:10.1016/j.crte.2015.11.004

Lavier, L.L., Manatschal, G., 2006. A mechanism to thin the continental lithosphere at magma-poor margins. Nature 440, 324-328. doi:10.1038/nature04608

Le Pichon, X., Chamot-Rooke, N., 1991. Extension of continental crust, Controversies in Modern Geology. Academic Press Limited, New-York, pp. 313-338.

Lecomte, E., L. Le Pourhiet, 0. Lacombe, and L. Jolivet (2011), A continuum mechanics approach to quantify brittle strain on weak faults: application to the extensional reactivation of shallow-dipping discontinuities, Geophys. J. Int., 184, 1-11, doi: 10.1111/j.1365-1246X.2010.04821.x.

Lentini, M.R., Fraser, S.I., Sumner, H.S., Davies, R.J., 2010. Geodynamics of the central South Atlantic conjugate margins: implications for hydrocarbon potential. Pet. Geosci. 16, 217-229. doi:10.1144/1354-079309-909

Levell, B., Argent, J., Doré, A.G., Fraser, S., 2010. Passive margins: overview. Geol. Soc. Lond. Pet. Geol. Conf. Ser. 7, 823-830. doi:10.1144/0070823 
Lister, G.S., Etheridge, M.A., Symonds, P.A., 1986. Detachment faulting and the evolution of passive continental margins. Geology 14, 246-250. doi:10.1130/00917613(1986)14<246:DFATEO>2.0.C0;2

Lizarralde, D., Axen, G.J., Brown, H.E., Fletcher, J.M., González-Fernández, A., Harding, A.J., Holbrook, W.S., Kent, G.M., Paramo, P., Sutherland, F., Umhoefer, P.J., 2007.

Variation in styles of rifting in the Gulf of California. Nature 448, 466-469. doi:10.1038/nature06035

Lohest, M., 1909. L’origine des veines et des géodes des terrains primaires de Belgique. Annales de la Société géologique de Belgique 36B, 275-282.

Magnavita, L.P., Davison, I., Kusznir, N.J., 1994. Rifting, erosion, and uplift history of the Recôncavo-Tucano-Jatobá Rift, northeast Brazil. Tectonics 13, 367-388. doi:10.1029/93TC02941

Manatschal, G., 2004. New models for evolution of magma-poor rifted margins based on a review of data and concepts from West Iberia and the Alps. Int. J. Earth Sci. 93, 432-466. doi:10.1007/s00531-004-0394-7

Marrett, R., Allmendinger, R.W., 1992. Amount of extension on "small" faults: An example from the Viking graben. Geology 20, 47-50. doi:10.1130/00917613(1992)020<0047:AOEOSF>2.3.CO;2

Maus, S., Barckhausen, U., Berkenbosch, H., Bournas, N., Brozena, J., Childers, V., Dostaler, F., Fairhead, J.D., Finn, C., von Frese, R.R.B., Gaina, C., Golynsky, S., Kucks, R., Lühr, H., Milligan, P., Mogren, S., Müller, R.D., Olesen, O., Pilkington, M., Saltus, R., Schreckenberger, B., Thébault, E., Caratori Tontini, F., 2009. EMAG2: A 2-arc min resolution Earth Magnetic Anomaly Grid compiled from satellite, airborne, and marine magnetic measurements. Geochem. Geophys. Geosystems 10, Q08005. doi:10.1029/2009GC002471 
Mbina Mounguengui, M., Guiraud, M., 2009. Neocomian to early Aptian syn-rift evolution of the normal to oblique-rifted North Gabon Margin (Interior and N’Komi Basins). Mar. Pet. Geol. 26, 1000-1017. doi:10.1016/j.marpetgeo.2008.11.001

McDermott, K., Gillbard, E., Clarke, N., 2015. From Basalt to Skeletons - the 200 millionyear history of the Namibian margin uncovered by new seismic data. First Break $33,77-85$.

Mehl, C., Jolivet, L., Lacombe, O., 2005. From ductile to brittle: evolution and localization of deformation below a crustal detachment (Tinos, Cyclades, Greece). Tectonics 24, TC4017, doi:4010.1029/2004TC001767.

Mehl, C., Jolivet, L., Lacombe, O., Labrousse, L., Rimmele, G., 2007. Structural evolution of Andros (Cyclades, Greece): a key to the behaviour of a (flat) detachment within an extending continental crust. Geol. Soc. Lond. Spec. Publ. 291, 41-73. doi:10.1144/SP291.3

Mello, M.R., Filho, N.C.D.A., Bender, A.A., Barbanti, S.M., Mohriak, W., Schmitt, P., Jesus, C.L.C.D., 2013. The Namibian and Brazilian southern South Atlantic petroleum systems: are they comparable analogues? Geol. Soc. Lond. Spec. Publ. 369, 249-266. doi:10.1144/SP369.18

Meyers, J.B., Rosendahl, B.R., Jr, J.A.A., 1996. Deep-penetrating MCS images of the South Gabon Basin: implications for rift tectonics and post-breakup salt remobilization. Basin Res. 8, 65-84. doi:10.1111/j.1365-2117.1996.tb00115.x

Michon, L., Merle, O., 2003. Mode of lithospheric extension: Conceptual models from analogue modeling. Tectonics 22, 1028. doi:10.1029/2002TC001435

Mjelde, R., Raum, T., Murai, Y., Takanami, T., 2007. Continent-ocean-transitions: Review, and a new tectono-magmatic model of the Vøring Plateau, NE Atlantic. J. Geodyn. 43, 374-392. doi:10.1016/j.jog.2006.09.013 
Mohn, G., Manatschal, G., Beltrando, M., Masini, E., Kusznir, N., 2012. Necking of continental crust in magma-poor rifted margins: Evidence from the fossil Alpine Tethys margins: NECKING OF CONTINENTAL CRUST. Tectonics 31, n/a-n/a. doi:10.1029/2011TC002961

Mohriak, W.U., Lira Rabelo, J., De Matos, R.D., De Barros, M.C., 1995. Deep seismic reflection profiling of sedimentary basins offshore Brazil: Geological objectives and preliminary results in the Sergipe Basin. J. Geodyn., Proceedings of the International Symposium on the Physics and Chemistry of the Upper Mantle 20, 515-539. doi:10.1016/0264-3707(95)00024-4

Mohriak, W.U., Nemcok, M.,and Enciso, G., 2008. South Atlantic divergent margin evolution: rift-border uplift and salt tectonics in the basins of SE Brazil. In: Pankhurst, R.]., Trouw, R.A.]., Brito Neves, B.B. \& de Wit, M.]. (eds.), West Gondwana pre-Cenozoic correlations across the South Atlantic region. Geological Society, London, Special Publications, v. 294, p. 365-398.

Mohriak, W.U., Mello, M.R., and Azambuja Filho, N.C., 2012. Tectonic reconstructions and petroleum system correlations in the southern south Atlantic: exploratory analysis and the search for a new hydrocarbon play. ln: N.C. Rosen et al. (eds.), New Understanding of the Petroleum systems of Continental Margins of the World, 32nd Annual GCssEPM Foundation Bob F. Perkins Research Conference, December 2-5, 2012, Houston, Texas, Expanded Abstracts, p.306-346.

Moulin, M., Aslanian, D., Olivet, J.-L., Contrucci, I., Matias, L., Géli, L., Klingelhoefer, F., Nouzé, H., Réhault, J.-P., Unternehr, P., 2005. Geological constraints on the evolution of the Angolan margin based on reflection and refraction seismic data (ZaïAngo project). Geophys. J. Int. 162, 793-810. doi:10.1111/j.1365- 
Moulin, M., Aslanian, D., Rabineau, M., Patriat, M., Matias, L., 2013. Kinematic keys of the Santos-Namibe basins. Geol. Soc. Lond. Spec. Publ. 369, 91-107. doi:10.1144/SP369.3

Müntener, O., Hermann, J., 2001. The role of lower crust and continental upper mantle during formation of non-volcanic passive margins: evidence from the Alps. Geol. Soc. Lond. Spec. Publ. 187, 267-288. doi:10.1144/GSL.SP.2001.187.01.13

Mutter, J.C., Talwani, M., Stoffa, P.L., 1982. Origin of seaward-dipping reflectors in oceanic crust off the Norwegian margin by "subaerial sea-floor spreading." Geology 10, 353. doi:10.1130/0091-7613(1982)10<353:00SRIO>2.0.CO;2

Mutter, J.C., 1985. Geophysics of the Polar Regions Seaward dipping reflectors and the continent-ocean boundary at passive continental margins. Tectonophysics 114 , 117-131. doi:10.1016/0040-1951(85)90009-5

Nissen, S.S., Hayes, D.E., Yao Bochu, Zeng Weijun, Chen Yongqin, Nu Xiaupin, 1995. Gravity, heat flow, and seismic constraints on the processes of crustal extension: northern margin of the South China Sea. J. Geophys. Res. 100, 22447-22483.

Osmundsen, P.T., Andersen, T.B., 2001. The middle Devonian basins of western Norway: sedimentary response to large-scale transtensional tectonics ? Tectonophysics 332, 51-68.

Osmundsen, P.T., Ebbing, J., 2008. Styles of extension offshore mid-Norway and implications for mechanisms of crustal thinning at passive margins. Tectonics 27, TC6016. doi:10.1029/2007TC002242

Pérez-Gussinyé, M., Ranero, C.R., Reston, T.J., Sawyer, D., 2003. Mechanisms of extension at nonvolcanic margins: Evidence from the Galicia interior basin, west of Iberia. J. Geophys. Res. Solid Earth 108, n/a-n/a. doi:10.1029/2001JB000901 
Péron-Pinvidic, G., Manatschal, G., 2008. The final rifting evolution at deep magma-poor passive margins from Iberia-Newfoundland: a new point of view. Int. J. Earth Sci. 98, 1581-1597. doi:10.1007/s00531-008-0337-9

Péron-Pinvidic, G., Manatschal, G., Masini, E., Sutra, E., Flament, J.M., Haupert, I., Unternehr, P., 2015. Unravelling the along-strike variability of the Angola-Gabon rifted margin: a mapping approach. Geol. Soc. Lond. Spec. Publ. 438, SP438.1. doi:10.1144/SP438.1

Péron-Pinvidic, G., Manatschal, G., Minshull, T.A., Sawyer, D.S., 2007.

Tectonosedimentary evolution of the deep Iberia-Newfoundland margins: Evidence for a complex breakup history. Tectonics 26, TC2011. doi:10.1029/2006TC001970

Pichot, T., Delescluse, M., Chamot-Rooke, N., Pubellier, M., Qiu, Y., Meresse, F., Sun, G., Savva, D., Wong, K.P., Watremez, L., Auxietre, J.L., 2014. Deep crustal structure of the conjugate margins of the SW South China Sea from wide-angle refraction seismic data. Mar. Pet. Geol. 58, 627-643.

Pindell, J., Graham, R., Horn, B., 2014. Rapid outer marginal collapse at the rift to drift transition of passive margin evolution, with a Gulf of Mexico case study. Basin Res. 26, 701-725. doi:10.1111/bre.12059

Planke, S., Symonds, P.A., Alvestad, E., Skogseid, J., 2000. Seismic volcanostratigraphy of large-volume basaltic extrusive complexes on rifted margins. J. Geophys. Res. Solid Earth 105, 19335-19351. doi:10.1029/1999JB900005

Proffett, J.M., 1977. Cenozoic geology of the Yerington district, Nevada, and implications for the nature and origin of Basin and Range faulting. Geol. Soc. Am. Bull. 88, 247266. doi:10.1130/0016-7606(1977)88<247:CGOTYD>2.0.CO;2 
Pubellier, M., Ego, F., Chamot-Rooke, N., Rangin, C., 2003. The building of pericratonic mountain ranges : structural and kinematic constraints applied to GIS-based reconstructions of SE Asia. Bull. Société Géologique Fr. 174, 561-584. doi:10.2113/174.6.561

Rabinowitz, P.D., LaBrecque, J.L., 1979. The Mesozoic South Atlantic Ocean and evolution of its continental margins. J. Geophys. Res. 84, 5973-6002. doi:10.1029/JB084iB11p05973

Raillard, S., Biteau, J. J., P. All, 1998. Abstract: Lower Congo Tertiary Basin - Offshore West Africa Structural Zonation and Evolution. AAPG Bull. 82 (1998). doi:10.1306/1D9BD7B3-172D-11D7-8645000102C1865D

Ranero, C.R., Pérez-Gussinyé, M., 2010. Sequential faulting explains the asymmetry and extension discrepancy of conjugate margins. Nature 468, 294-299. doi:10.1038/nature09520

Reston, T.J., 1988. Evidence for shear zones in the lower crust offshore Britain. Tectonics 7, 929-945. doi:10.1029/TC007i005p00929

Reston, T.J., 2005. Polyphase faulting during the development of the west Galicia rifted margin. Earth Planet. Sci. Lett. 237, 561-576. doi:10.1016/j.epsl.2005.06.019

Reston, T.J., 2007. The formation of non-volcanic rifted margins by the progressive extension of the lithosphere: the example of the West Iberian margin. Geol. Soc. Lond. Spec. Publ. 282, 77-110. doi:10.1144/SP282.5

Reston, T.J., McDermott, K.G., 2011. Successive detachment faults and mantle unroofing at magma-poor rifted margins. Geology 39, 1071-1074. doi:10.1130/G32428.1

Reston, T.J., McDermott, K., 2014. An assessment of the cause of the "extension discrepancy" with reference to the west Galicia margin. Basin Res. 26, 135-153. doi:10.1111/bre.12042 
Ricard, Y., Froidevaux, C., 1986. Stretching instabilites and lithospheric boudinage. J. Geophys. Res. 91, 8314-8324

Ricard, Y., Froidevaux, C., Simpson, R., 1987. Spectral analysis of topography and gravity in the Basin and Range Province. Tectonophysics, Deep Internal Processes and Continental Rifting 133, 175-187. doi:10.1016/0040-1951(87)90262-9

Riis, F., Vollset, J., Sand, M., 1986. Tectonic Development of the Western Margin of the Barents Sea and Adjacent Areas 131, 661-675.

Ryan, W.B.F., Carbotte, S.M., Coplan, J.O., O’Hara, S., Melkonian, A., Arko, R., Weissel, R.A., Ferrini, V., Goodwillie, A., Nitsche, F., Bonczkowski, J., Zemsky, R., 2009. Global Multi-Resolution Topography synthesis: GLOBAL MULTI-RESOLUTION TOPOGRAPHY SYNTHESIS. Geochem. Geophys. Geosystems 10, n/a-n/a. doi:10.1029/2008GC002332

Sapin, F., Ringenbach, J.-C., Rives, T., Pubellier, M., 2012. Counter-regional normal faults in shale-dominated deltas: Origin, mechanism and evolution. Mar. Pet. Geol. 37, 121-128. doi:10.1016/j.marpetgeo.2012.05.001

Savva, D., Meresse, F., Pubellier, M., Chamot-Rooke, N., Lavier, L., Po, K.W., Franke, D., Steuer, S., Sapin, F., Auxietre, J.L., Lamy, G., 2013. Seismic evidence of hyperstretched crust and mantle exhumation offshore Vietnam. Tectonophysics 608, 7283. doi:10.1016/j.tecto.2013.07.010

Savva, D., Pubellier, M., Franke, D., Chamot-Rooke, N., Meresse, F., Steuer, S., Auxietre, J.L., 2014. Different expressions of rifting on the South China Sea margins. Mar. Pet. Geol., Evolution, Structure, and Sedimentary Record of the South China Sea and Adjacent Basins 58, Part B, 579-598. doi:10.1016/j.marpetgeo.2014.05.023 
Schlüter, H.U., Hinz, K., Block, M., 1996. Tectono-stratigraphic terranes and detachment faulting of the South China Sea and Sulu Sea. Mar. Geol. 130, 39-78. doi:10.1016/0025-3227(95)00137-9

Sibuet, J.-C., 1992. New constraints on the formation of the non-volcanic continental Galicia-Flemish Cap conjugate margins. J. Geol. Soc. 149, 829-840. doi:10.1144/gsjgs.149.5.0829

Skogseid, J., Pedersen, T., Eldholm, O., Larsen, B.T., 1992. Tectonism and magmatism during NE Atlantic continental break-up: the Vøring Margin. Geol. Soc. Lond. Spec. Publ. 68, 305-320. doi:10.1144/GSL.SP.1992.068.01.19

Skogseid, J., 2014. Extension on rifted continental margins: Observation vs. models. Geophys. Res. Abstr. Vol. 16, EGU General Assembly 2014. http://meetingorganizer.copernicus.org/EGU2014/EGU2014-14913.pdf

Soto, M., Morales, E., Veroslavsky, G., de Santa Ana, H., Ucha, N., Rodríguez, P., 2011. The continental margin of Uruguay: Crustal architecture and segmentation. Mar. Pet. Geol. 28, 1676-1689. doi:10.1016/j.marpetgeo.2011.07.001

Stica, J.M., Zalán, P.V., Ferrari, A.L., 2014. The evolution of rifting on the volcanic margin of the Pelotas Basin and the contextualization of the Paraná-Etendeka LIP in the separation of Gondwana in the South Atlantic. Mar. Pet. Geol. 50, 1-21. doi:10.1016/j.marpetgeo.2013.10.015

Talwani, M., Eldholm, O., 1977. Evolution of the Norwegian-Greenland Sea. Geol. Soc. Am. Bull. 88, 969-999. doi:10.1130/0016-7606(1977)88<969:EOTNS>2.0.C0;2

Taylor, B., Hayes, D.E., 1983. Origin and History of the South China Sea Basin, in: Hayes, D.E. (Ed.), The Tectonic and Geologic Evolution of Southeast Asian Seas and Islands: Part 2. American Geophysical Union, pp. 23-56. 
Taylor, B., Hayes, D.E., 1980. The Tectonic Evolution of the South China Basin, in: Hayes, D.E. (Ed.), The Tectonic and Geologic Evolution of Southeast Asian Seas and Islands. American Geophysical Union, pp. 89-104.

Teisserenc, P., Villemin, J., 1990. Sedimentary basin of Gabon; geology and oil systems. AAPG Mem. 48, 117-199.

Teixell, A., Labaume, P., Lagabrielle, Y., 2016. The crustal evolution of the west-central Pyrenees revisited: Inferences from a new kinematic scenario. Comptes Rendus Geosci., From rifting to mountain building: the Pyrenean Belt 348, 257-267. doi:10.1016/j.crte.2015.10.010

Theissen, S., Rüpke, L.H., 2010. Feedbacks of sedimentation on crustal heat flow: New insights from the Vøring Basin, Norwegian Sea. Basin Res. 22, 976-990. doi:10.1111/j.1365-2117.2009.00437.x

Tsikalas, F., Faleide, J.I., Kusznir, N.J., 2008. Along-strike variations in rifted margin crustal architecture and lithosphere thinning between northern Vøring and Lofoten margin segments off mid-Norway. Tectonophysics, Geodynamics of Lithospheric Extension 458, 68-81. doi:10.1016/j.tecto.2008.03.001

Unternehr, P., Péron-Pinvidic, G., Manatschal, G., Sutra, E., 2010. Hyper-extended crust in the South Atlantic: in search of a model. Pet. Geosci. 16, 207-215. doi:10.1144/1354-079309-904

Van Avendonk, H.J.A., Lavier, L.L., Shillington, D.J., Manatschal, G., 2009. Extension of continental crust at the margin of the eastern Grand Banks, Newfoundland. Tectonophysics, Role of magmatism in continental lithosphere extension continental lithosphere extension 468, 131-148. doi:10.1016/j.tecto.2008.05.030

Vendeville, B., 1987. Champs de failles et tectonique en extension : Modélisation expérimentale (phd thesis). Université Rennes 1. 
Wang, Y., Fan, W., Zhang, G., Zhang, Y., 2013. Phanerozoic tectonics of the South China Block: Key observations and controversies. Gondwana Res. 23, 1273-1305. doi:10.1016/j.gr.2012.02.019

Watts, A.B., Stewart, J., 1998. Gravity anomalies and segmentation of the continental margin offshore West Africa. Earth Planet. Sci. Lett. 156, 239-252. doi:10.1016/S0012-821X(98)00018-1

White, R., McKenzie, D., 1989. Magmatism at rift zones: The generation of volcanic continental margins and flood basalts. J. Geophys. Res. Solid Earth 94, 7685-7729. doi:10.1029/JB094iB06p07685

White, R.S., Spence, G.D., Fowler, S.R., McKenzie, D.P., Westbrook, G.K., Bowen, A.N., 1987. Magmatism at rifted continental margins. Nature 330, 439-444. doi:10.1038/330439a0

Whitmarsh, R.B., Sawyer, D.S., Klaus, A., Masson, D.G. (Eds.), 1996. Proceedings of the Ocean Drilling Program, 149 Scientific Results. Ocean Drilling Program.

Xiao, H.-B., Dahlen, F.A., Suppe, J., 1991. Mechanics of extensional wedges. J. Geophys. Res. Solid Earth 1978-2012 96. doi:10.1029/91JB00222

Yin, A., 1994. Mechanics of wedge-shaped fault blocks: 2. An elastic solution for extensional wedges. J. Geophys. Res. Solid Earth 99, 7045-7055. doi:10.1029/93JB02389

Ziegler, P.A., 1983. Crustal thinning and subsidence in the North Sea. Nature 304, 561561. doi:10.1038/304561a0 


\section{Short CVs and photographs of the authors}

\section{- Camille Clerc}

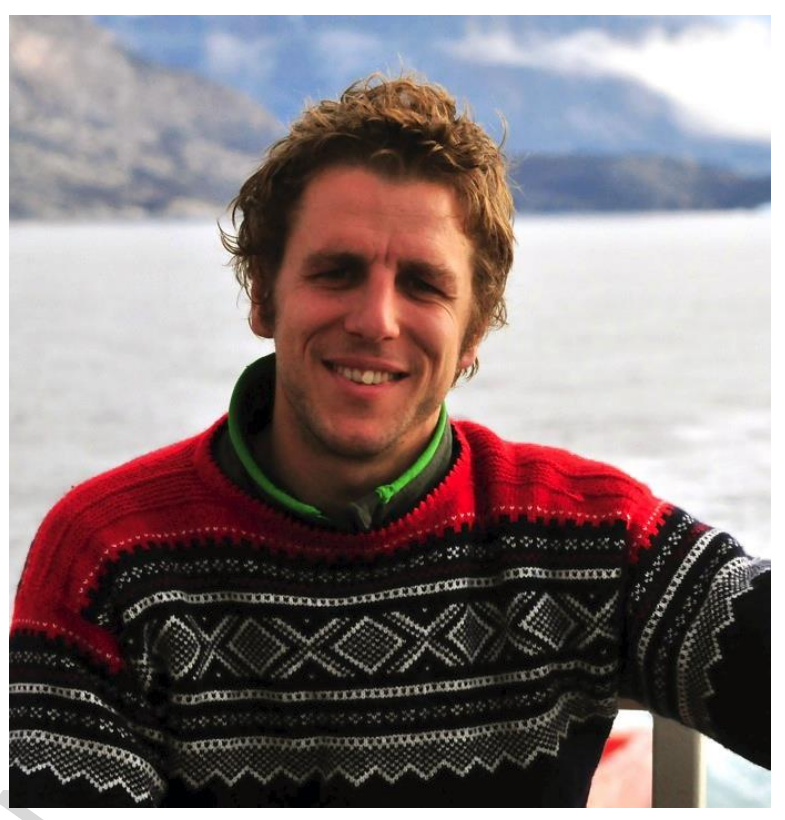

Camille Clerc is associate professor at the University of New Caledonia. He earned his Ph.D. in structural geology in 2012 at the Université Pierre et Marie Curie in Paris for studying the aborted cretaceous rift system fossilized in the Pyrenees.

Since 2009, Camille is studying the architecture and thermal evolution of passive margins, both from fossil margins exhumed in orogens (Pyrenees) and from present day passive margins.

Recruited at the University of New Caledonia in 2016, he now explores the extension of the drawned continent Zealandia and investigates the geological setting of the New Caledonian ophiolite.

\section{- Jean-Claude Ringenbach}




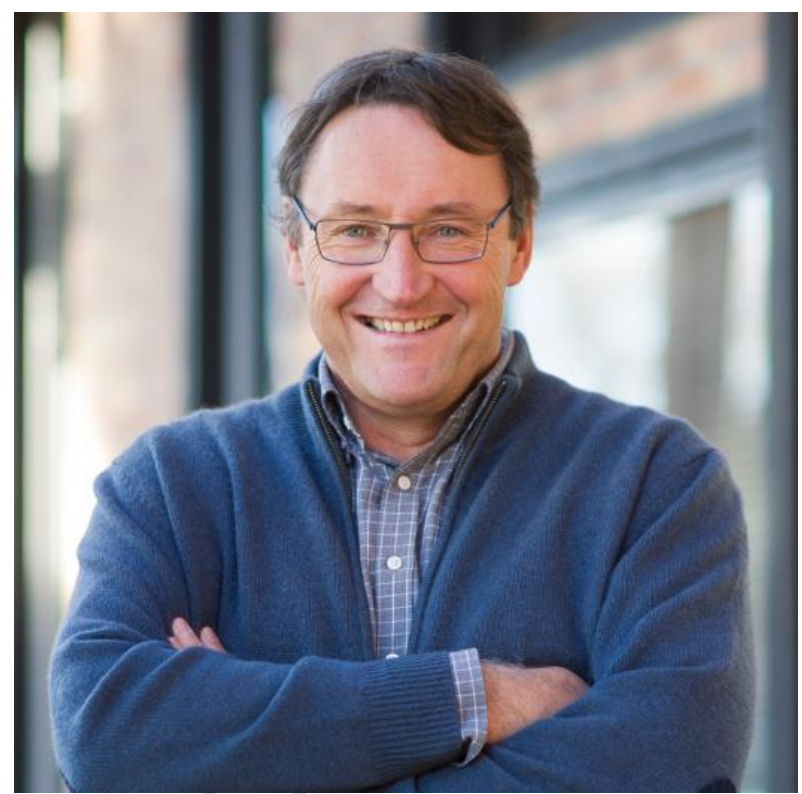

Jean-Claude Ringenbach studied in Ecole Normale Supérieure and he earned his Ph.D. in structural geology and geodynamics in 1992 from Nice University, France. He worked for Elf and then Total since 1992. Exploration Geologist in Total Affiliates, he occupied several positions: basin geologist and deep offshore Exploration Manager (1997-2001) and Chief Geologist in Libya (2001-2004). From 2004 to 2007 JC took over the Fold-and-Thrust Belts thematic in the New Venture Group in Paris. From 2007-2013 he was the Head of the Structural Geology Group in Pau and has been appointed Total's Expert in Structural Geology in 2013.

JC's experience encompasses various fields of basin structural geology and is based on a large worldwide geological knowledge. His expertise is supported by academic projects on Fold-and-Thrust Belts, Salt Tectonics and Continental Margins.

\section{- Laurent Jolivet}




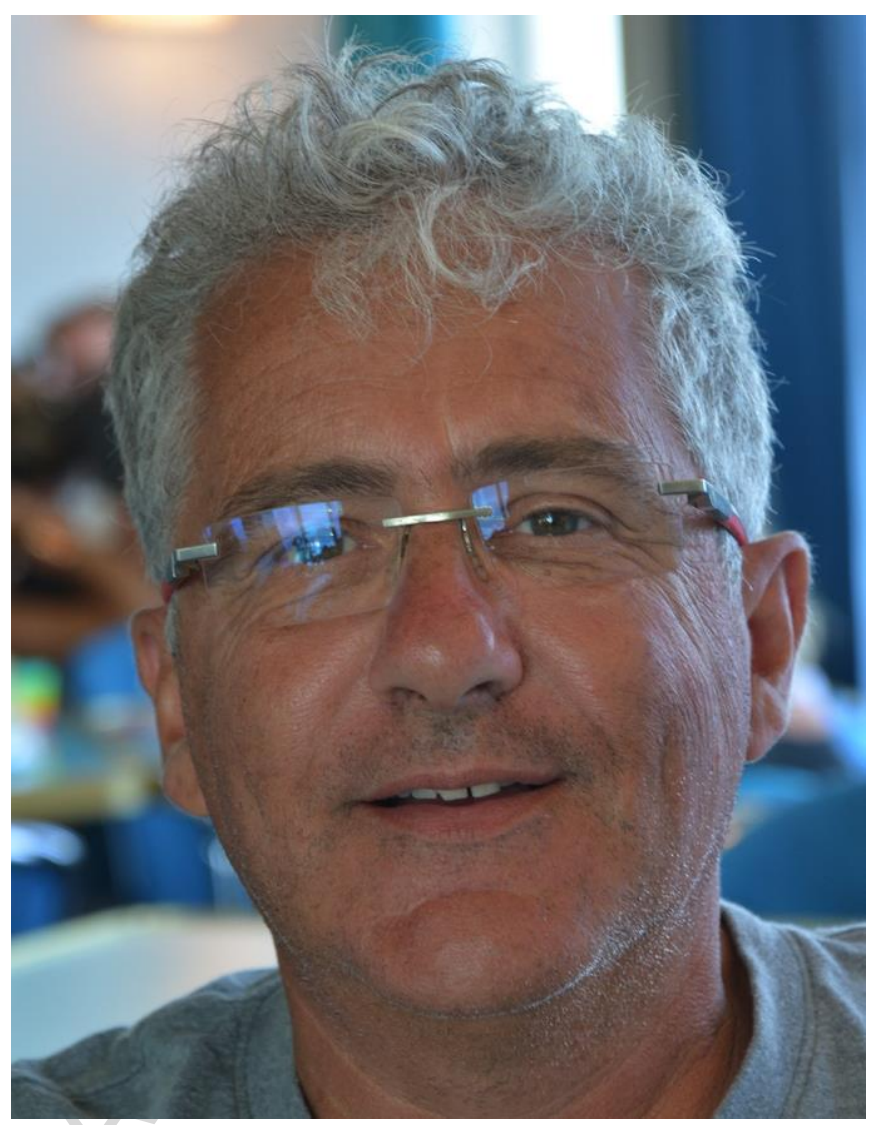

Laurent Jolivet is professor of the University of Orléans (France). He received his Ph.D. from Université Pierre et Marie Curie in Paris. He has developed research in tectonics and geodynamics, focussing on upper plate deformation in subduction zones, back-arc basins opening, exhumation of HP-LT metamorphic rocks, lithosphere-asthenosphere coupling, metamorphic core-complexes and detachments, dynamics of extension, Mediterranean tectonics and geodynamics, tectonic evolution of East Asia. He is the coPI of the ERC advanced research grant RHEOLITH together with E. Burov, a project aimed at a better understanding of strain localisation in the continental lithosphere.

\section{- Jean-François Ballard}




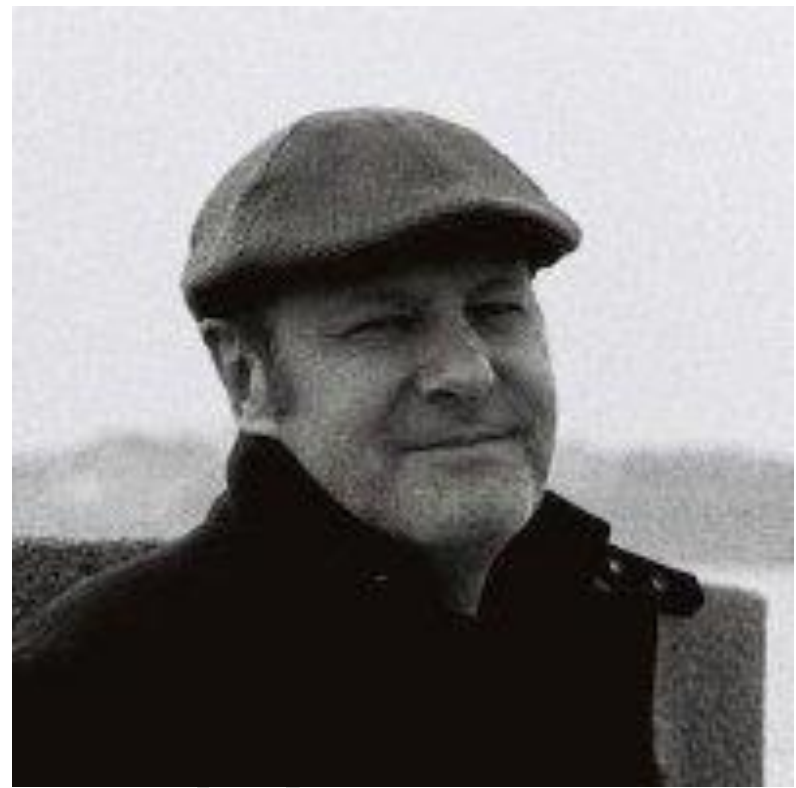

JF earned his Ph.D. in structural geology in 1989 from Rennes University, France under direction of Prof. Jean-Pierre Brun (analog modeling of compressive and extensional systems, field works in Brittany, France). In 1989, JF started working at IFP and as an external consultant for Elf, which he joined in 1991. Geologist in the structural group he did field works in Argentina, Venezuela, Peru and structural studies on various tectonic context from margin to fold-and-thrust belts. From 2001 to 2004, he integrated Total E\&P Bolivie as an exploration geologist. Since 2005, JF is based in Pau and mainly dedicates himself to structural support to Total affiliates (Bolivia, Nigeria, Gabon,... ) and headquarters group (new ventures etc..). 
a)

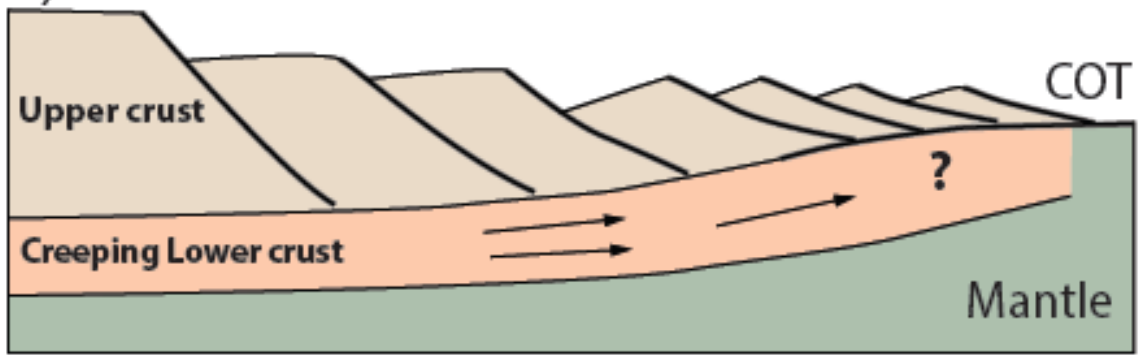

b)

Driscoll \& Karner, 1998

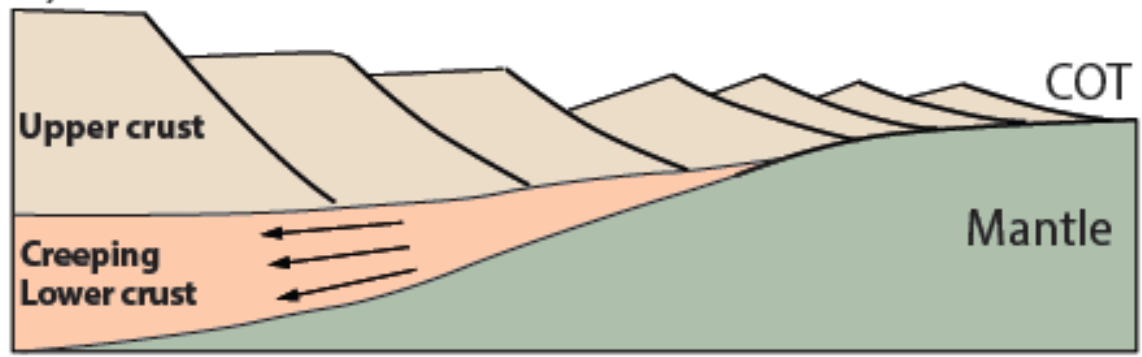

Brun \& Beslier, 1996

c)

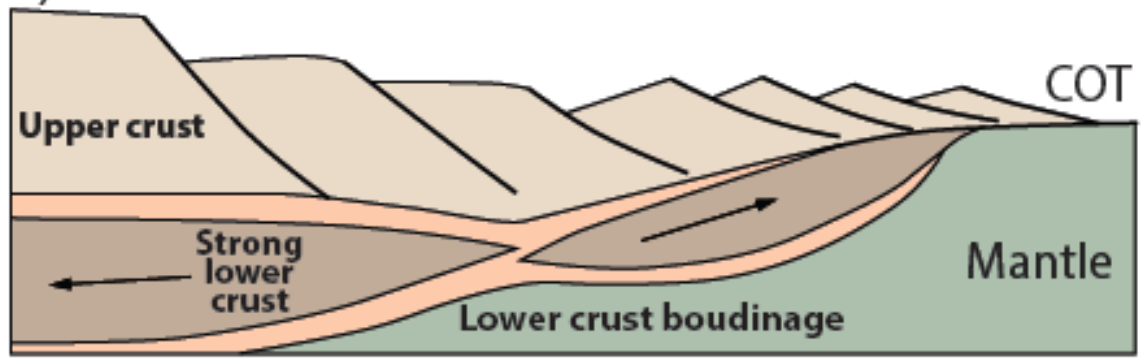

Reston 1988

d)

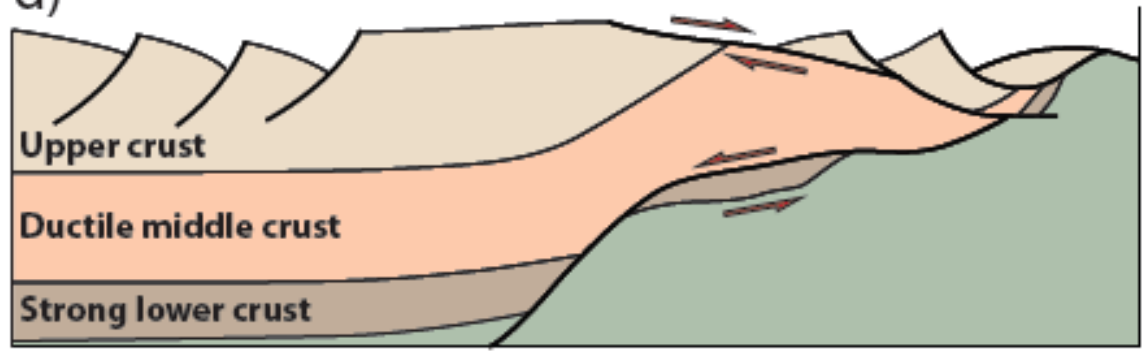

e)

Manatschal, 2004 - Lavier \& Manatschal, 2009

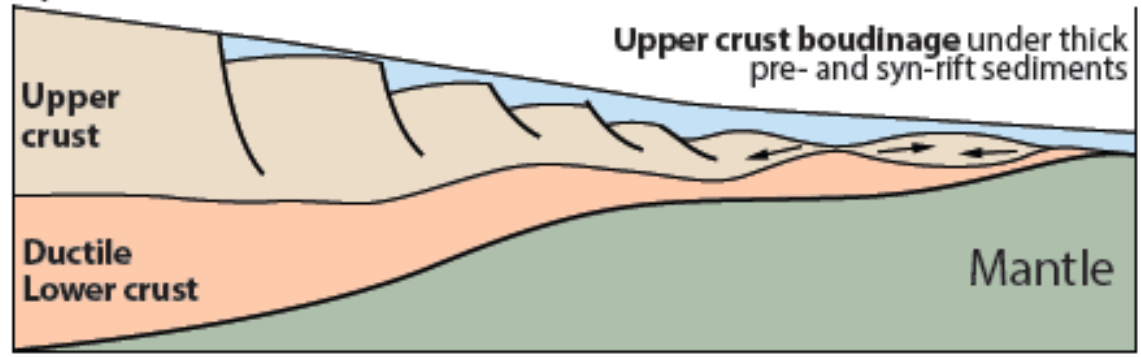

Clerc \& Lagabrielle, 2014

Fig. 1 


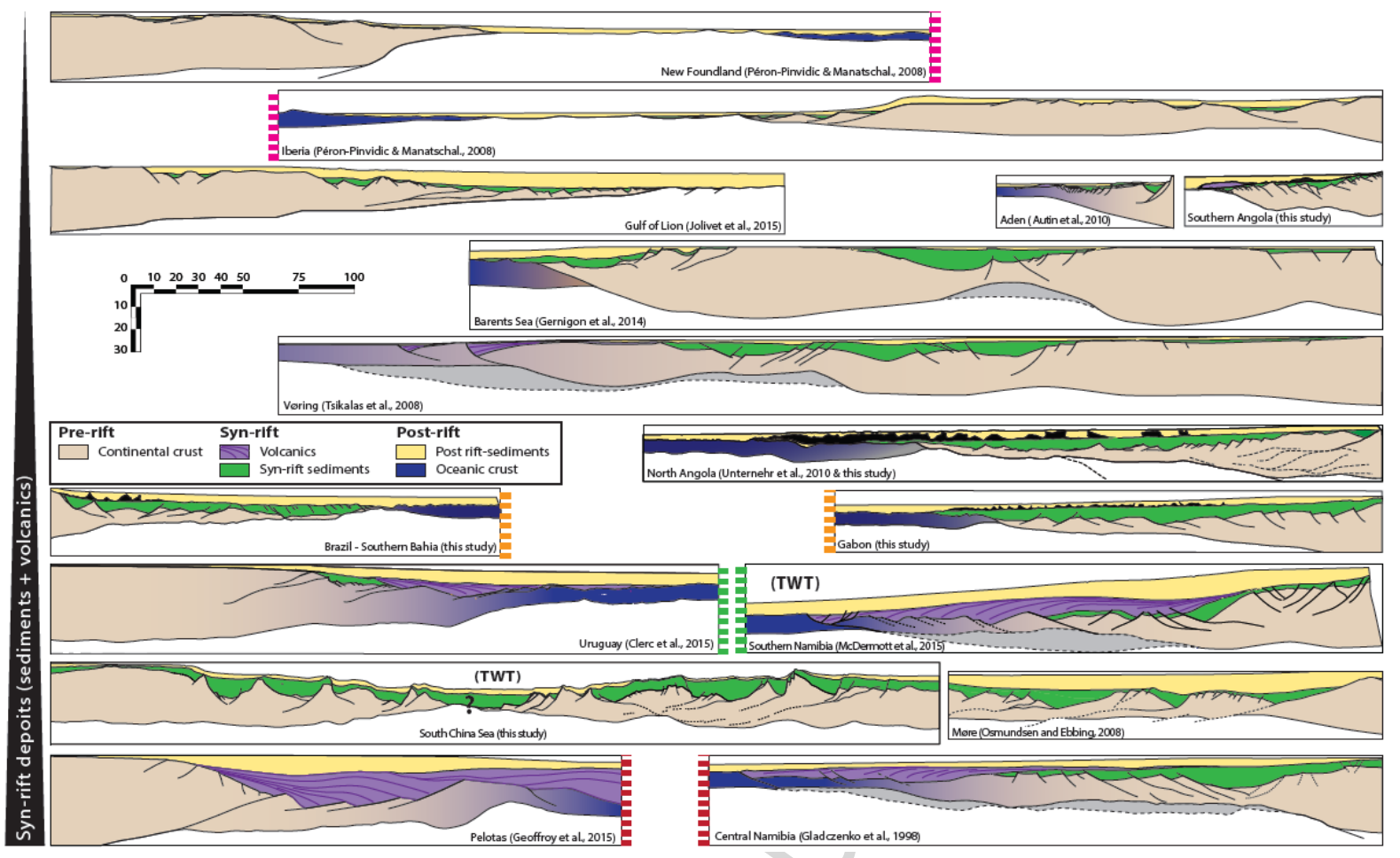

Fig. 2 


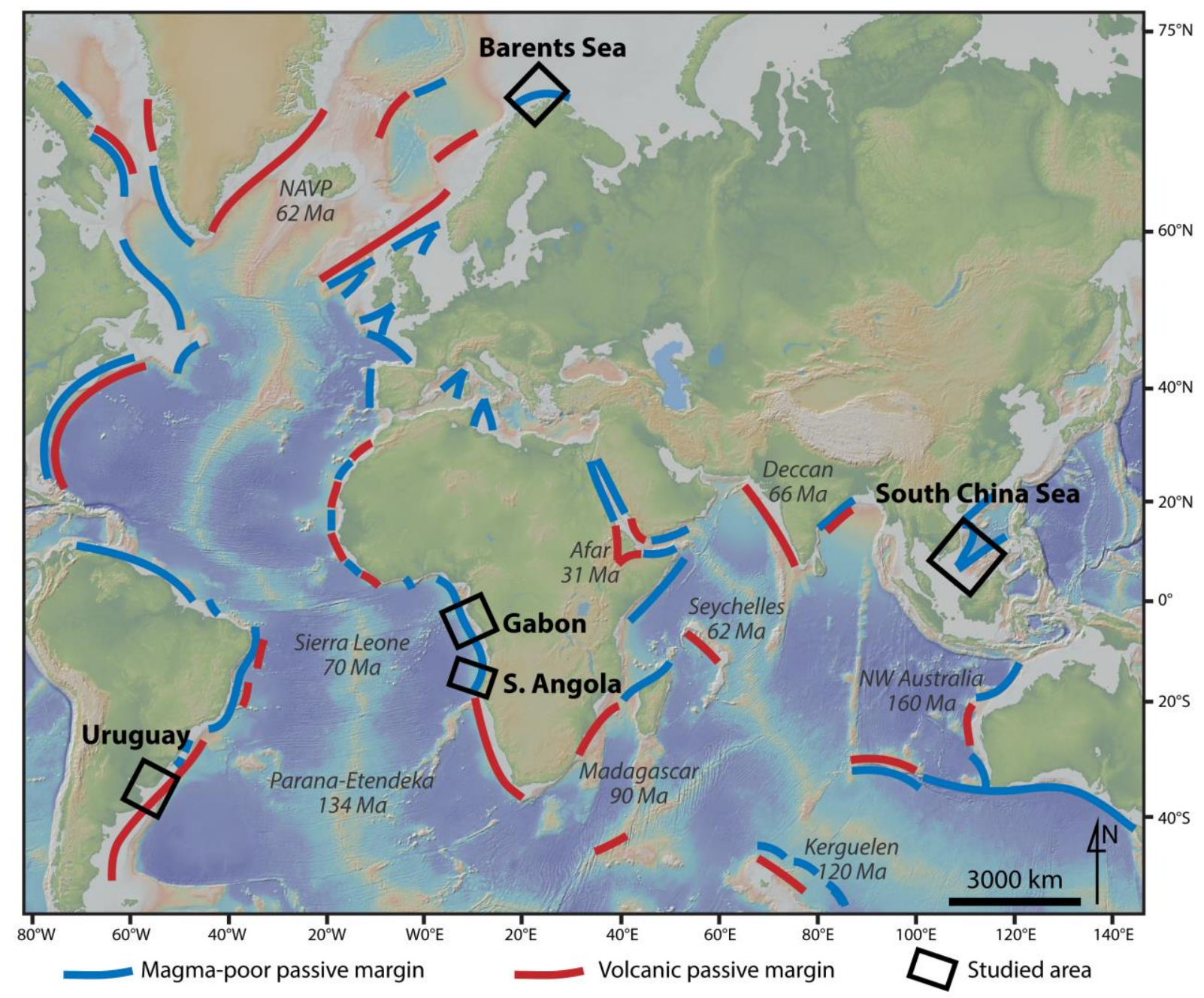

Fig. 3 

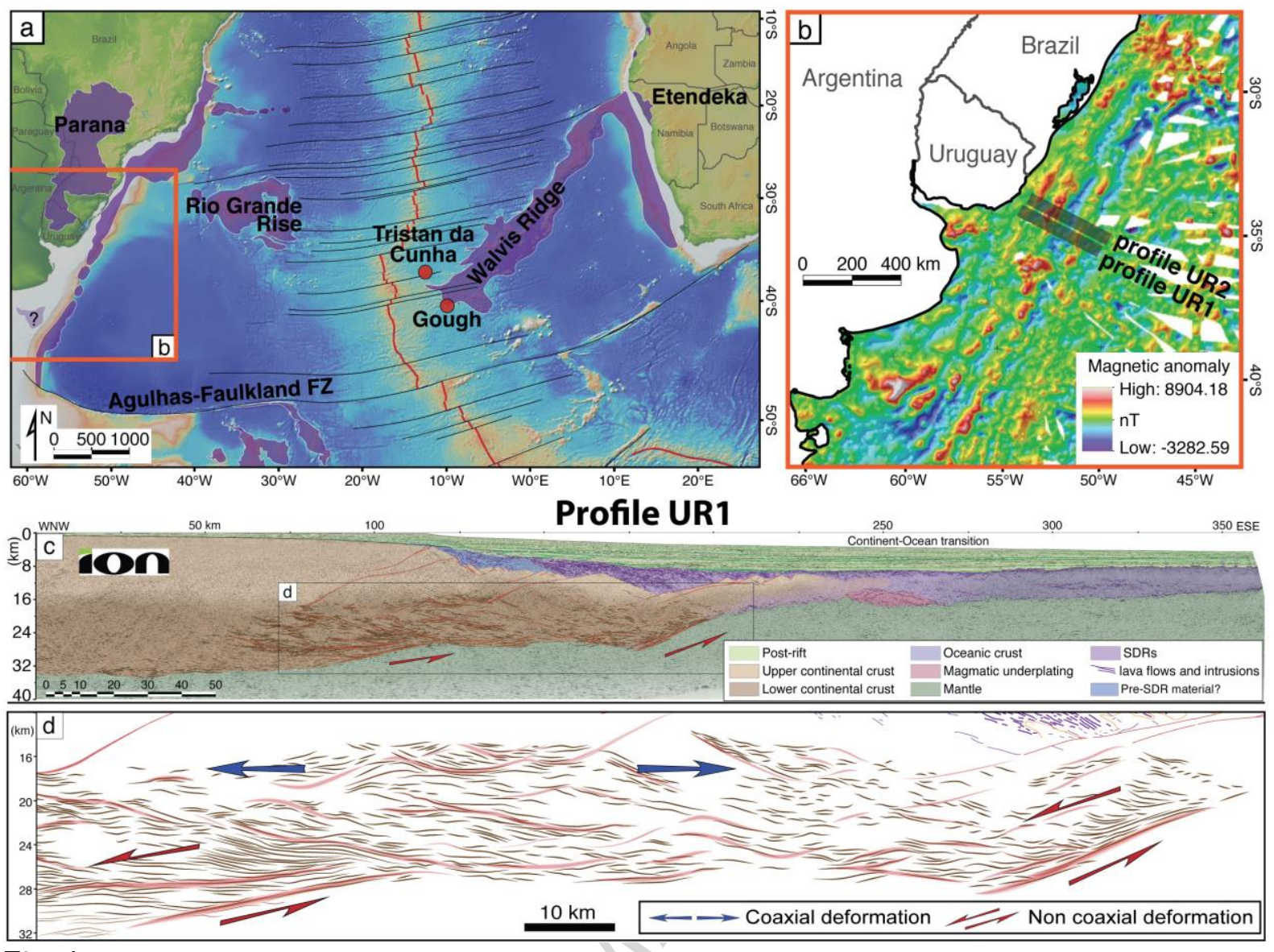

Fig. 4 


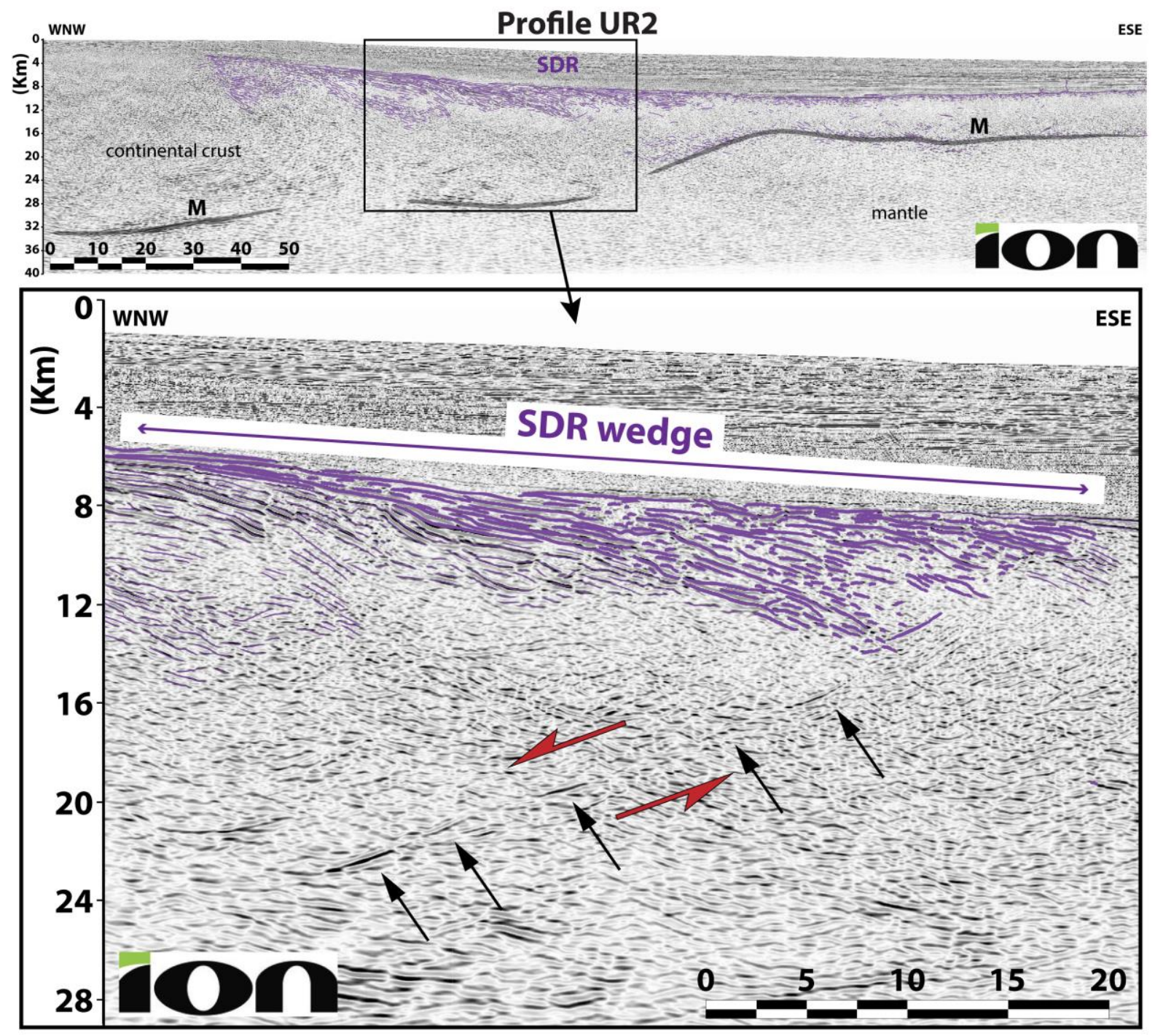

Fig. 5 


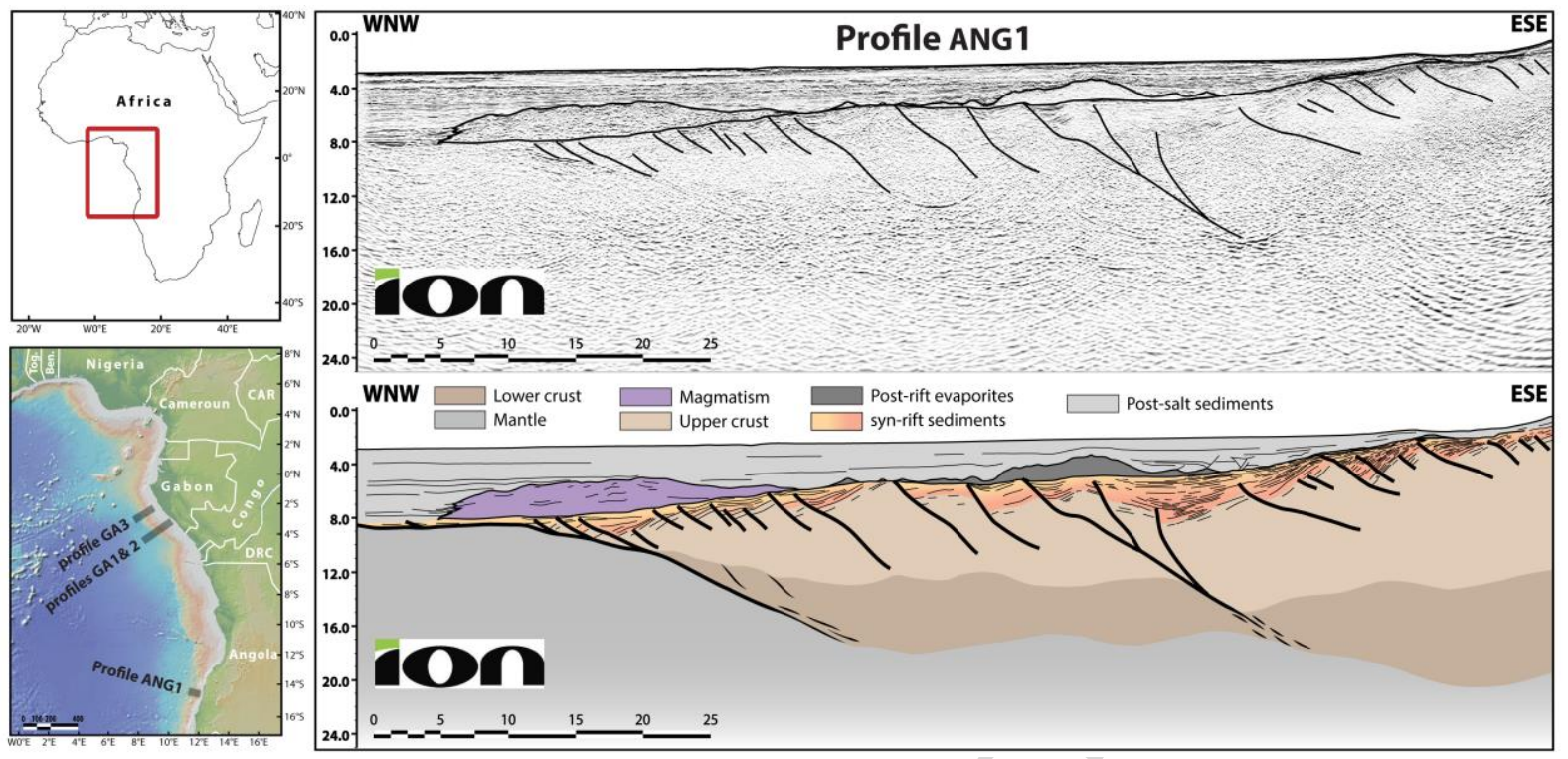

Fig. 6 

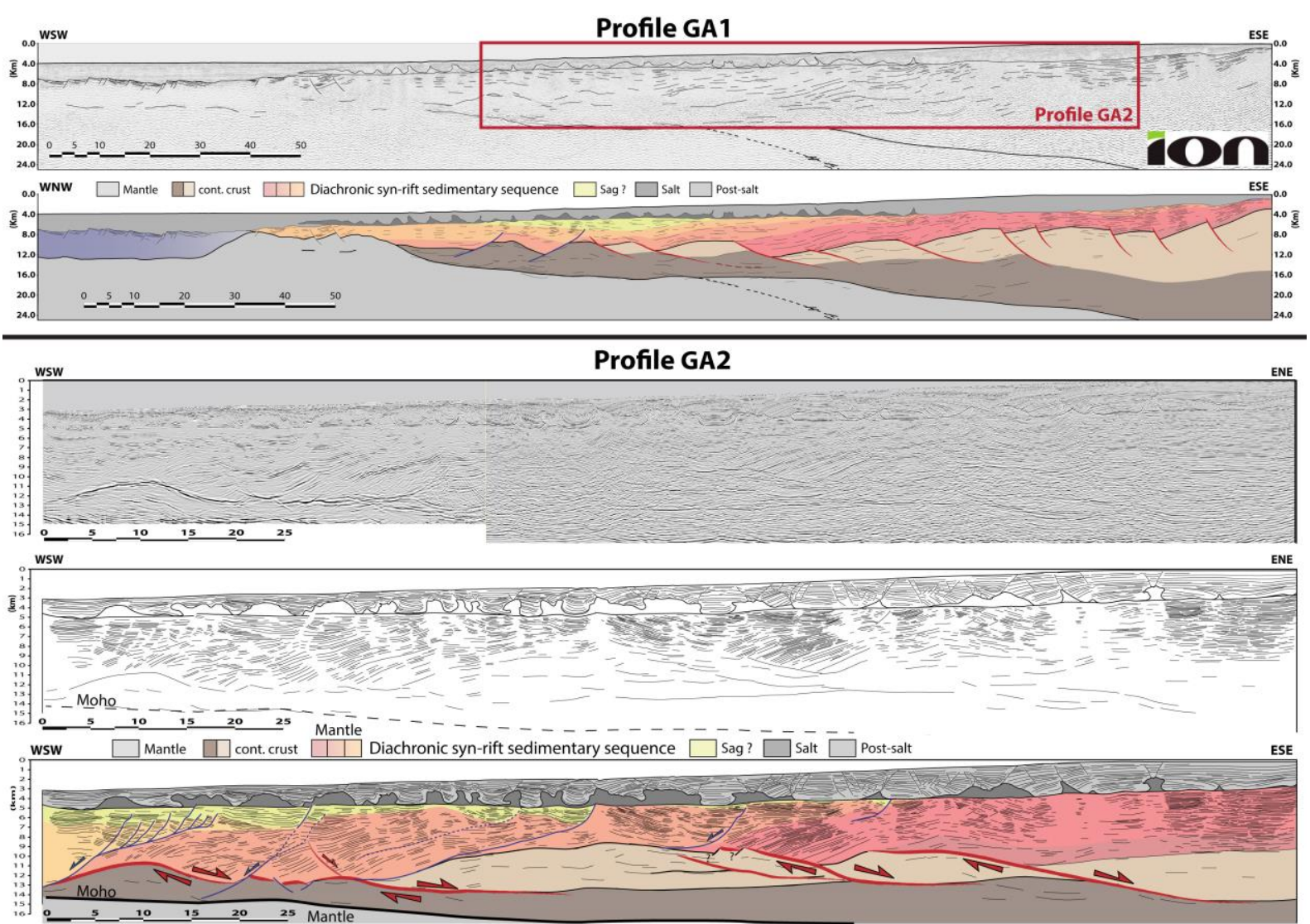

Fig. 7 


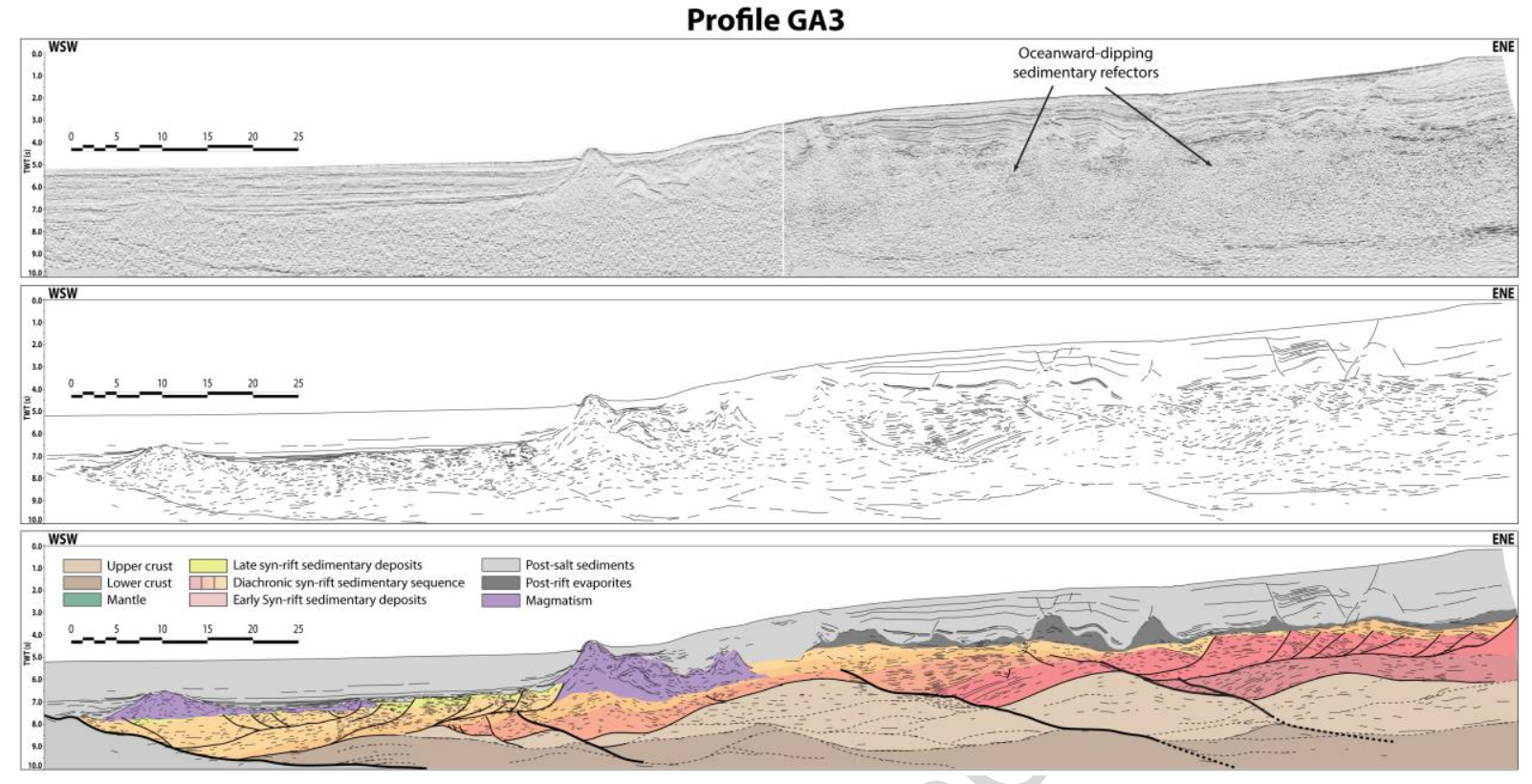

Fig. 8 


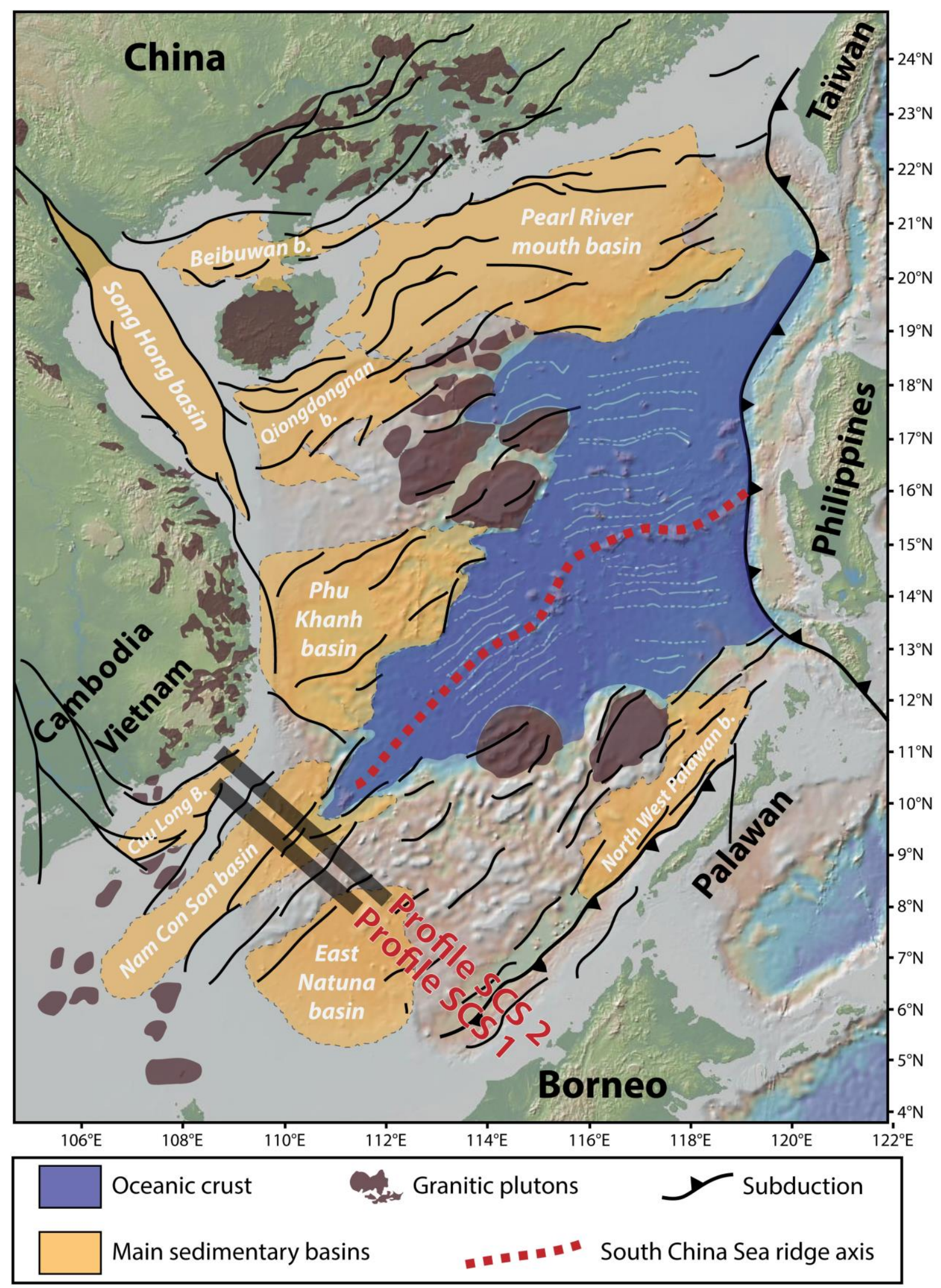

Fig. 9 


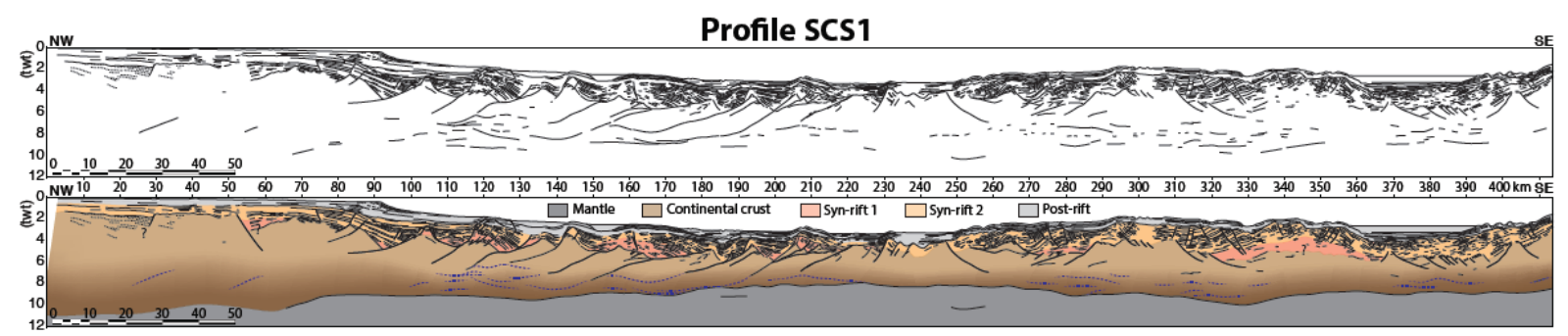

Fig. 10 


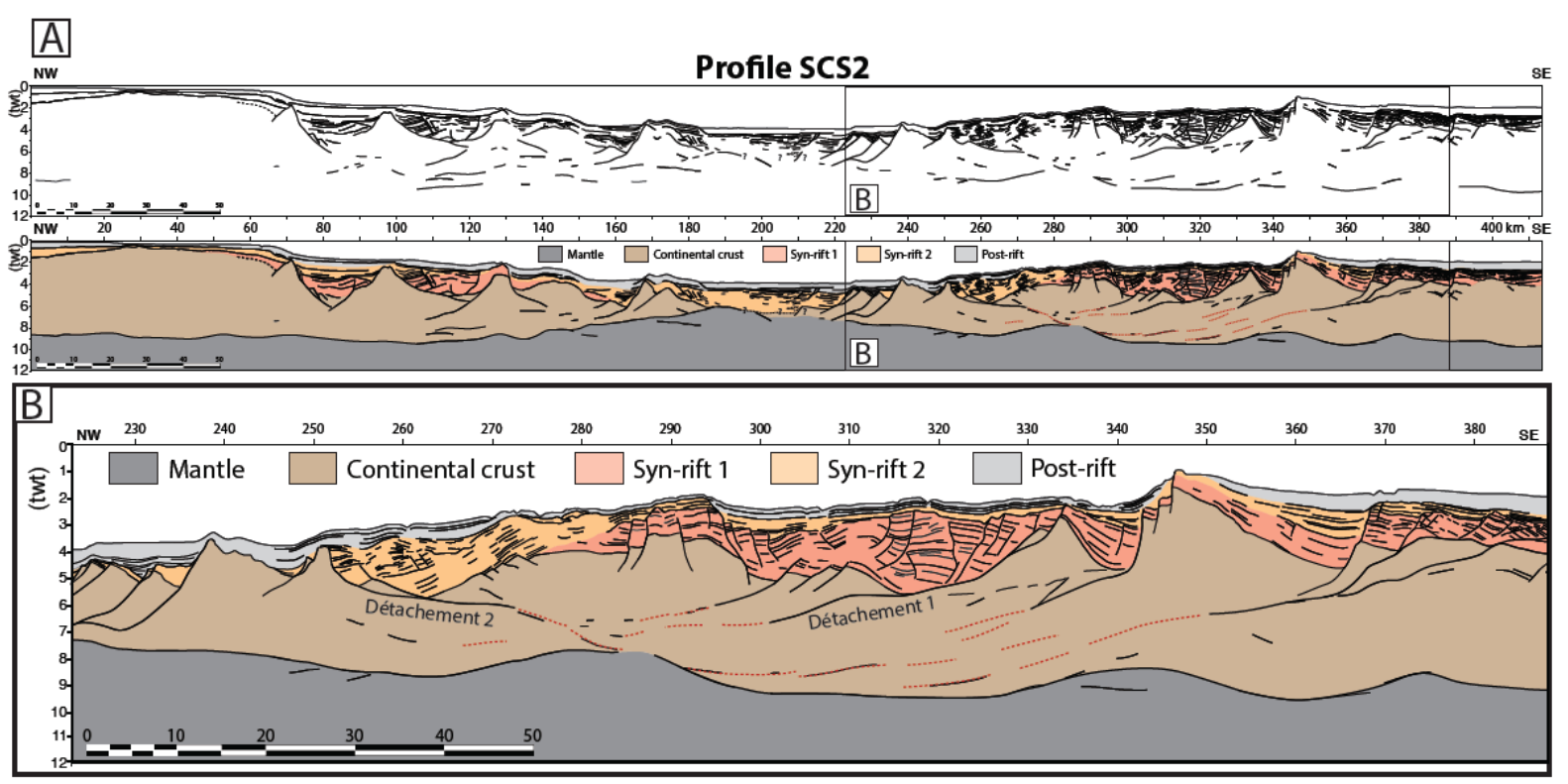

Fig. 11 

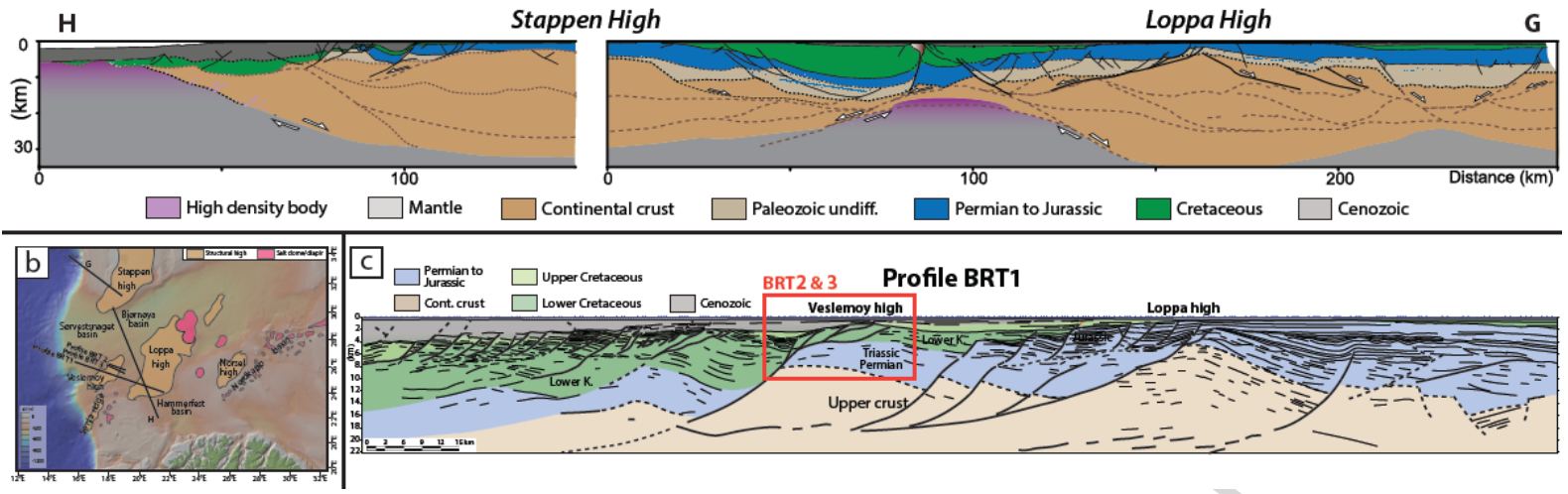

\begin{tabular}{|l|l|}
\hline C \\
\hline
\end{tabular}

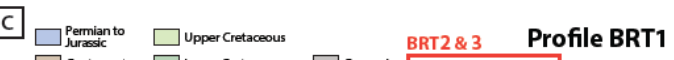
$\square$ Cont. crust $\square$ Lower Cretaceous $\square$ Cenozoic

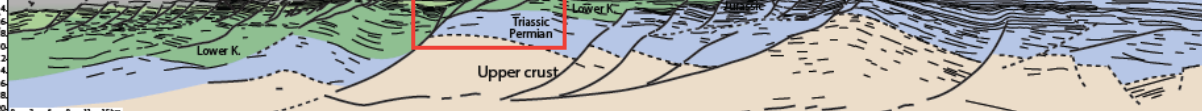

Fig. 12 
a

Profile BRT2

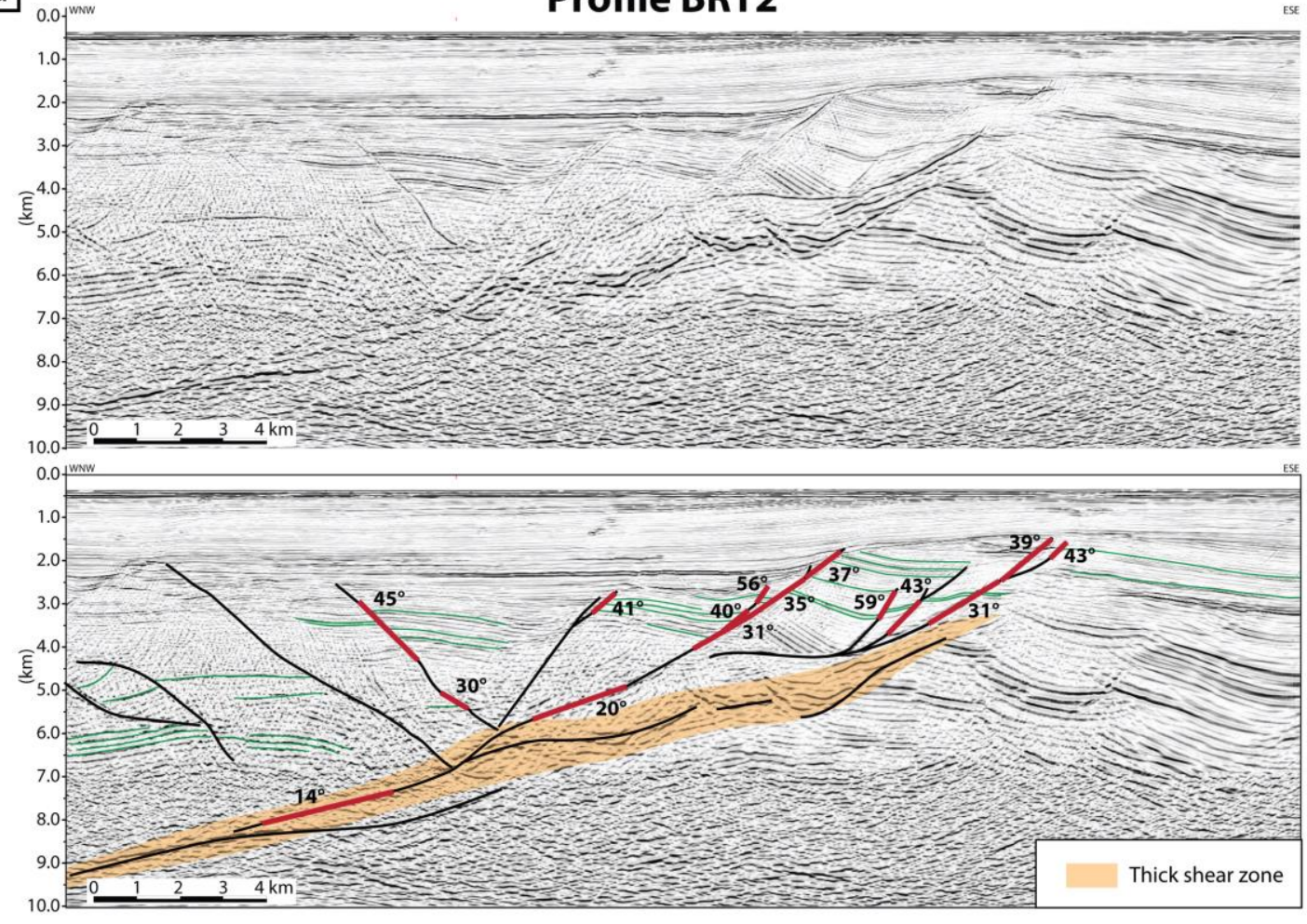

b
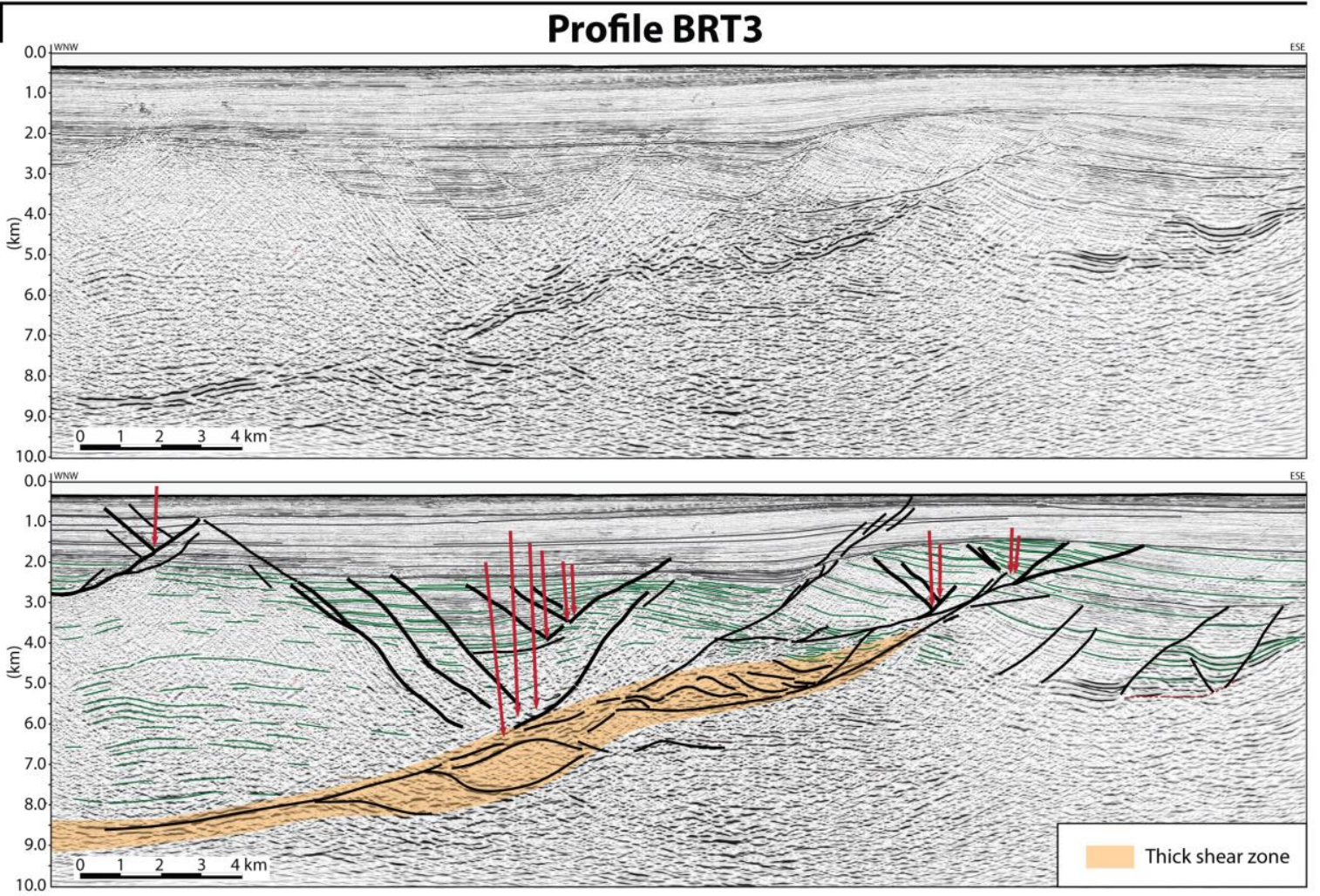

Major principal stress $\sigma_{1}=$ bissector of conjugate antithetic normal faults

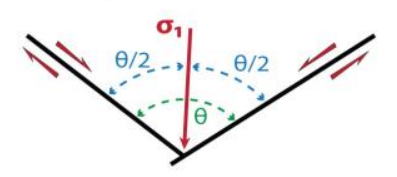

Fig. 13 


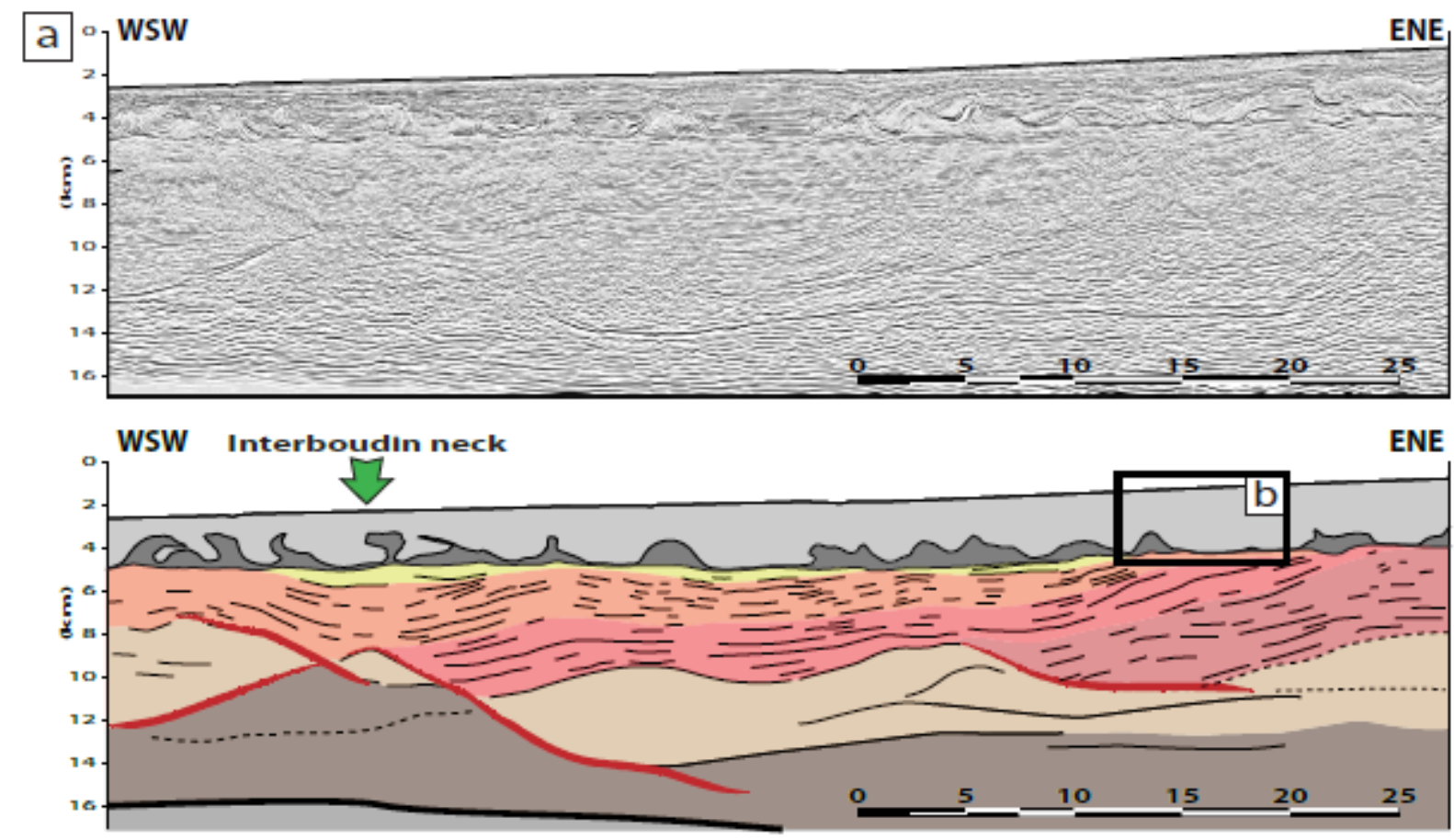

b
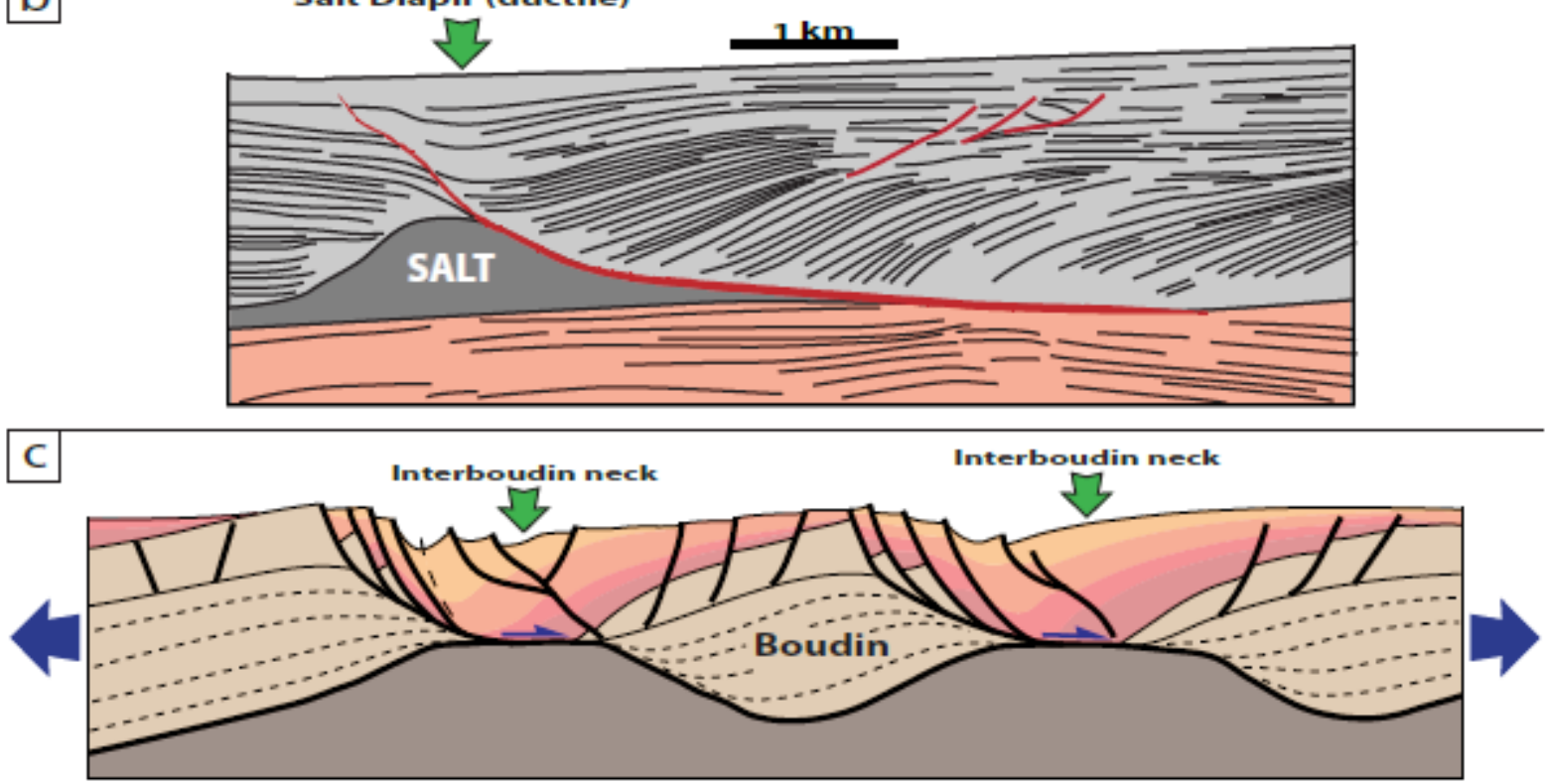

Fig. 14 

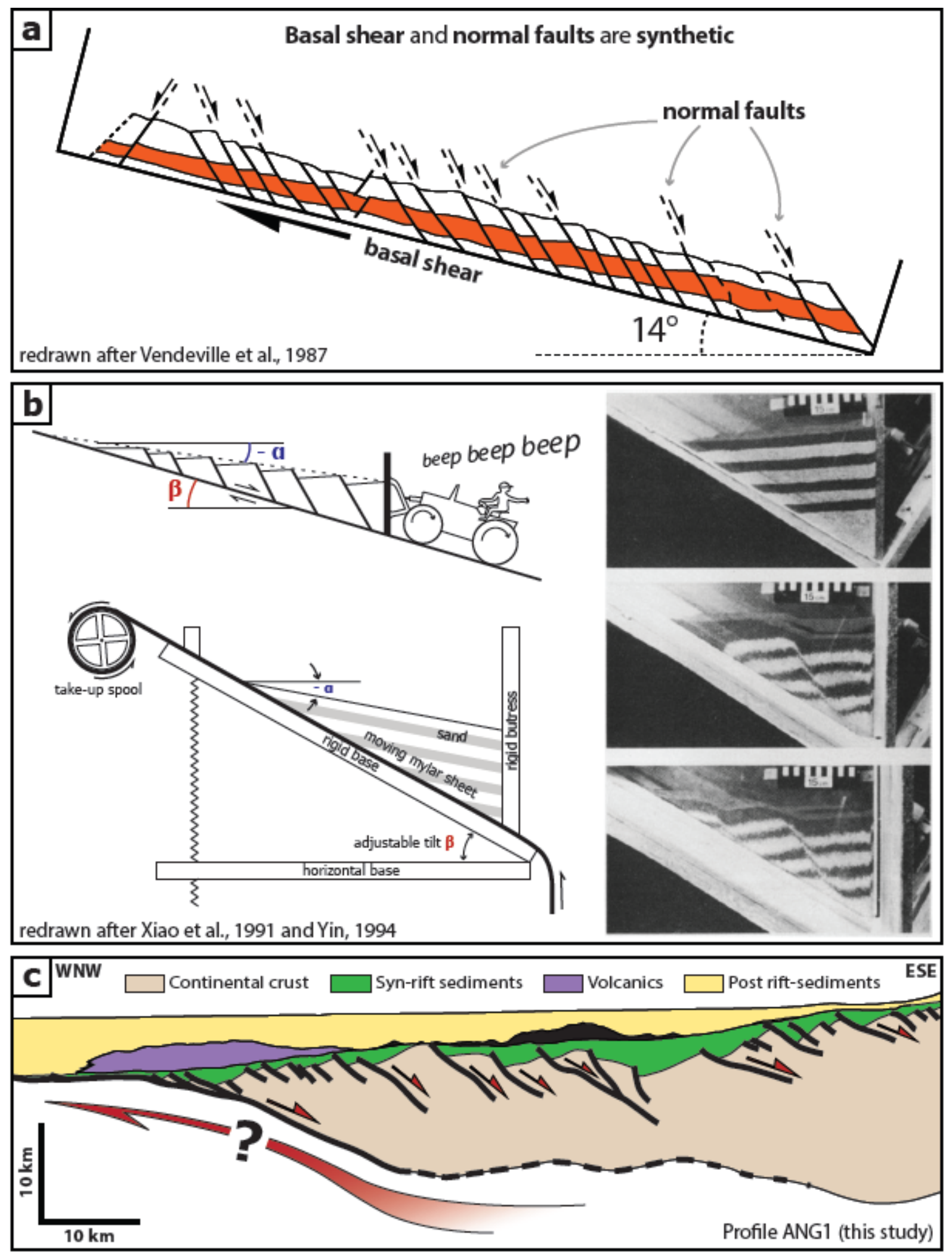

Fig. 15 
$a$ Negative thrust reactivation e.g.: Raillard et al., 1998; Sapin et al., 2012

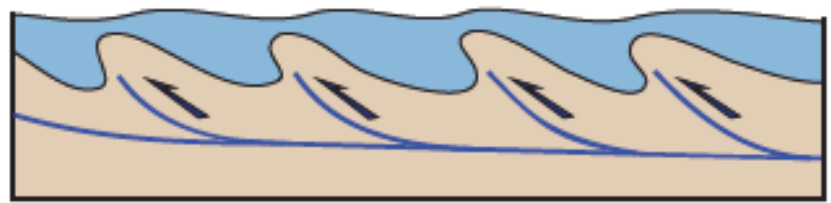

11 inversion

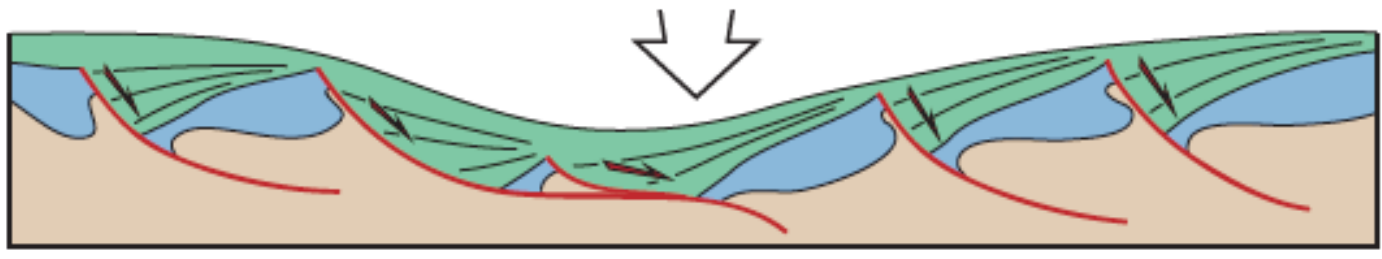

b Influence of mantle/crust relative motion upper plate (CDNF) Lower plate

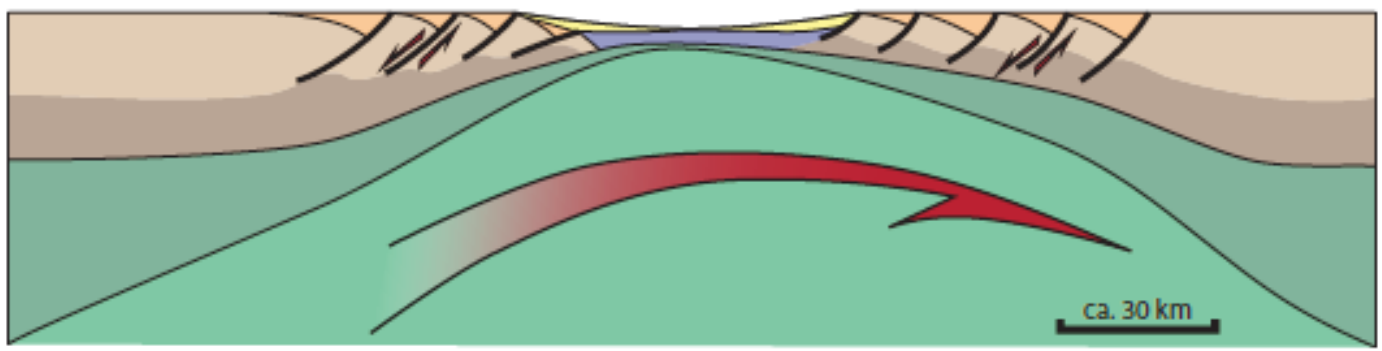

C Crustal collapse above a plume-related topographic anomaly

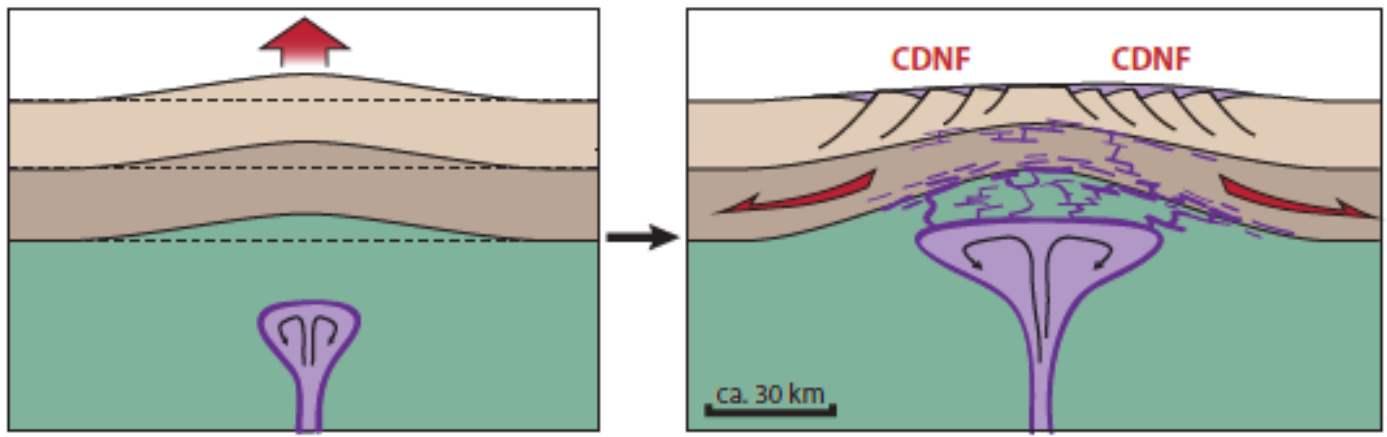

Fig. 16 

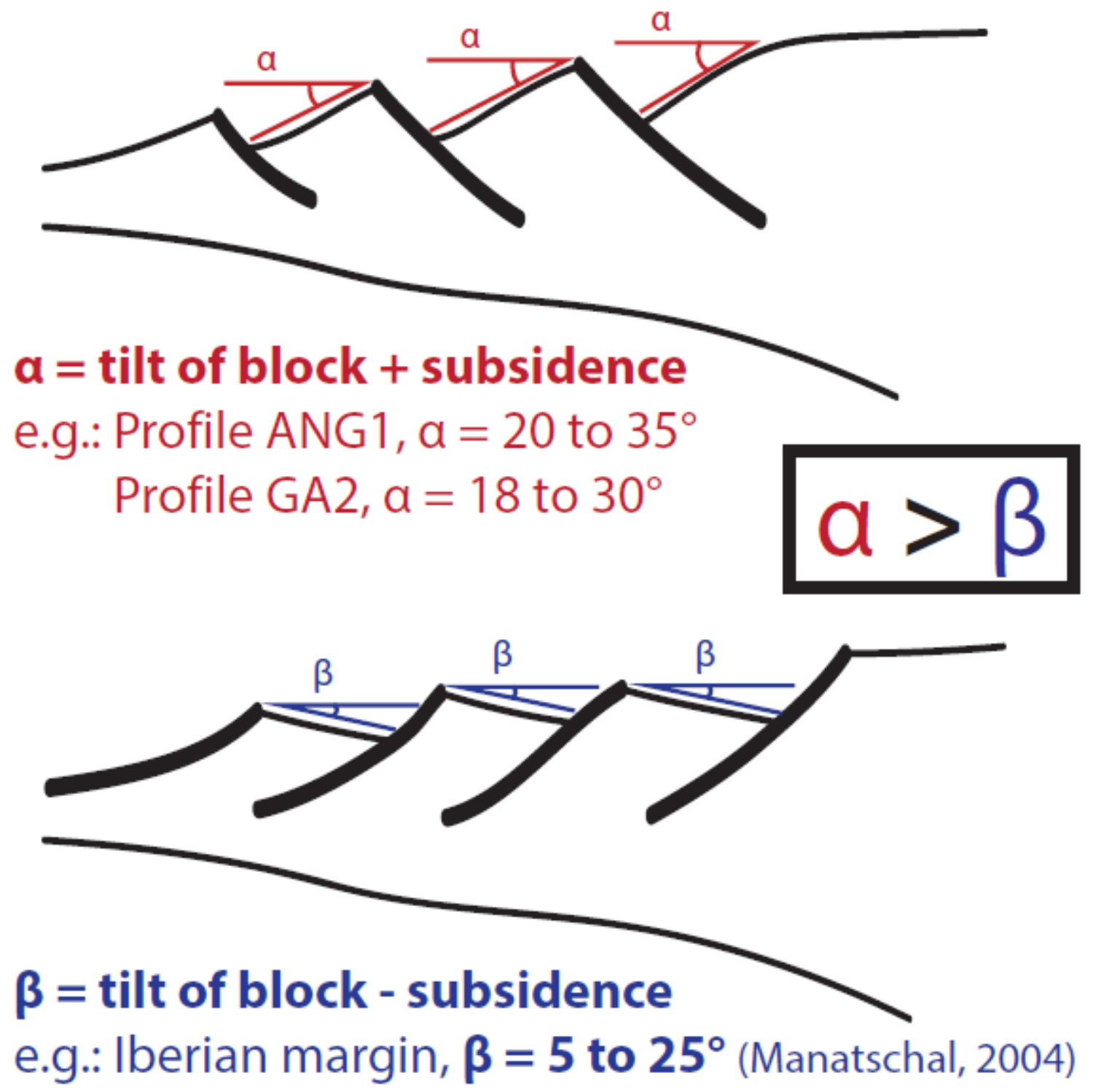

Fig. 17 
a

Volcanic Passive Margin

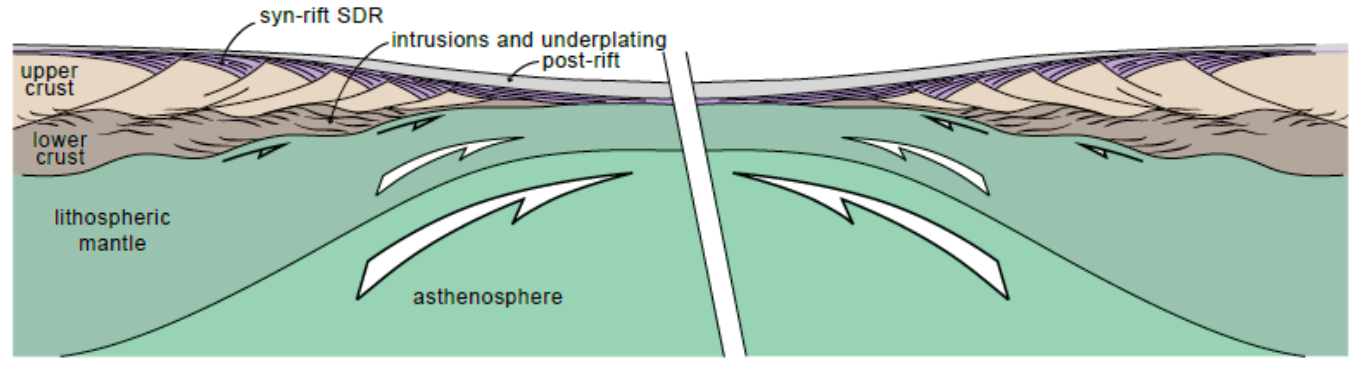

b

Magma-Poor Passive Margin

Hot margin type

or Cold margin type
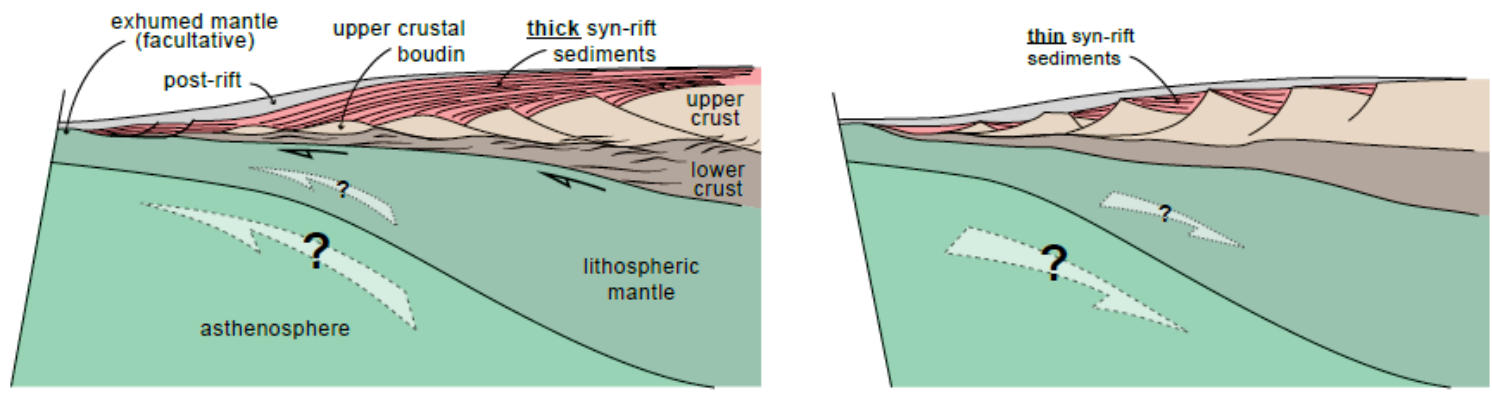

Fig. 18 


\section{Crustal boudinage}

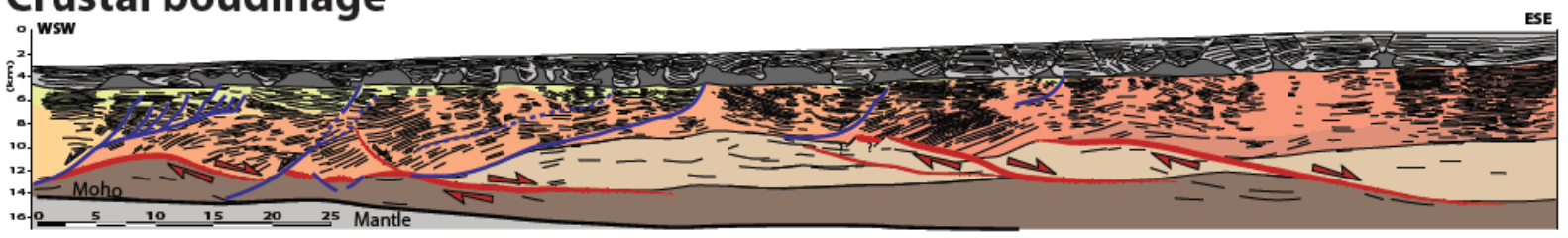

\section{Continentward Dipping Normal Faults (CDNF)}

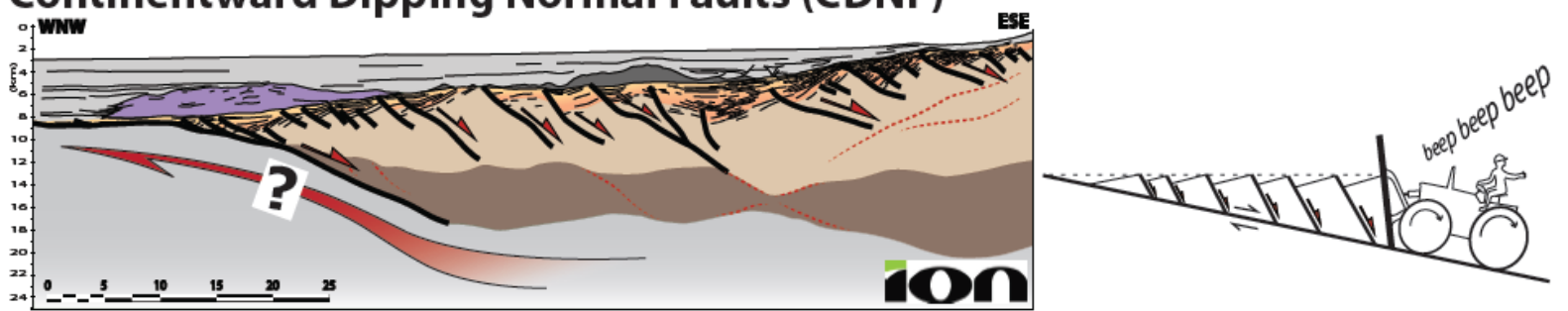

\section{Ductile lower crust}

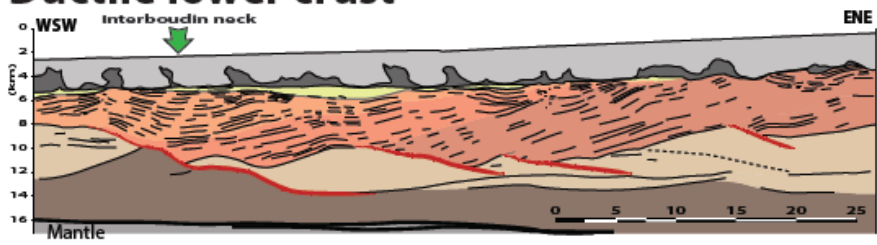

Low angle normal faults

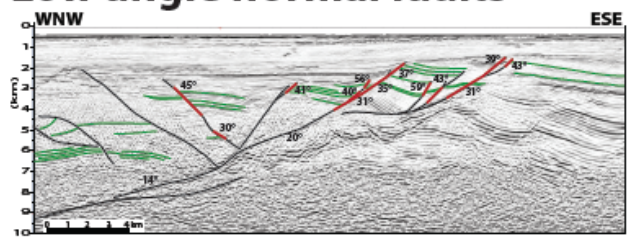

$\square$ Mantle $\square$ cont. crust $\square \square$ Diachronic syn-rift sedimentary sequence

$\square$ sag?

Magmatism

$\square$ Salt $\square$ Post-salt

Graphical abstract 